\title{
STREDOVEKÝ HRÁDOK V DIVINKE A DIVINE ${ }^{1}$
}

\author{
M I C H A L H O L E Š Č́́ - A N D R E A S L A N Á
}

\begin{abstract}
Medieval Stronghold in Divinka and Divina. Article focuses on the archaeological excavations of a strongold situated on the border of cadastral areas of the villages Divina and Divinka, conducted by the authors of the paper in two summer seasons of 2018 and 2019. The site is situated on a conical hill with a two-tiered platform, on the top of which stood probably a wooden tower-like structure, protected by three lines of fortifications. A rampart was built at the foot of this castle, from which a wooden-clay structure has been preserved. At the edge of the main plateau was a second wooden-clay rampart reinforced with stone, which succumbed to fire. The last line of the fortification was a palisade, which protected the tower-like building. Based on a radiocarbon analysis supported by archaeological material, ceramics and arrowheads, it is possible to date the construction of the stronghold to the final quarter of the $13^{\text {th }}$ century. Written reports on the construction of the site are non-existant. Based on the territorial ownership of the area, it can be assumed that it took place under the responsibility of the ancestors of the Balaša family, Biter, his brother Petr and his heirs. The fortification either served as the estate of the administrator of the valley of the stream Divina, or as a checkpoint on the Váh road or its branch. The demise of the locality, which lasted only a short time due to the compactness of the material, can be connected most probably with the territorial ambitions of Matthew III Csák of Trenčín, after which the process of restoration no longer took place and the newly created village Divina began to grow under the researched hill.
\end{abstract}

Keywords: Northwestern Slovakia, Medieval Period, stronghold, arrowheads, pottery, fortification, radiocarbon dating.

ÚVOD

Skúmaná poloha Hradisko sa nachádza v katastri obce Divinka okolo kóty 508,2 m vo východnej časti pohoria Javorníkov, nad rovnomenným potokom Divinka na zalesnenom vŕšku výrazne odčlenenom od okolia. Na tomto vrchu je situované stredoveké opevnenie. $\mathrm{V}$ odborných príspevkoch bol v minulosti hrádok umiestňovaný do katastra obce Divina (Beňko 1985, 9; Malec 2010, 122; Moravč́k 1991, 14; Petrovský-Šichman 1964, 71). V súvislosti s aktuálnym výskumom hrádku sa jeho presnejšou lokalizáciou zistilo, že podstatná čast' telesa vrchu Hradisko, a tým aj stredoveký hrádok leží v katastri obce Divinka, pričom jeho severná hrana tvorí chotárnu hranicu.

Okolie skúmanej lokality bolo osídlené od paleolitu, s ojedinelými nálezmi aj z neolitu a eneolitu (Slaná 2018, 43, 44), obdobia lužickej (Fusek/Holeščák 2018) a púchovskej (Staneková 2013) kultúry, ako aj vo včasnostredovekom období, okrem iného najmä na blízkom Vel'kom vrchu (Fusek/Holeščák 2019). Skúmaná lokalita v Divinke na vrchu Hradisko patrí do skupiny drevozemných hrádkov, ktoré sa odlišujú od kamenných hradov minimálnym zastúpením murovanej architektúry (Ruttkay 1992, 256, 257). A. Habovštiak pod týmto typom fortifikácie rozumie menšie lokality umiestnené na prirodzenom terénnom vyvýšení s drevozemným opevnením s maximálnym rozmerom $10-40 \mathrm{~m}$ (Habovštiak 1972), čomu zodpovedá aj hrádok na lokalite Hradisko. Podla klasifikácie F. Jašša spadá lokalita do skupina hrádkov bez umelého navýšenia na prirodzených vyvýšeninách (Jaššo 2007, 136, 137). Po prvý krát bola táto lokalita v odbornej literatúre opísaná A. Petrovským-Šichmanom, ktorý tu realizoval terénny prieskum v roku 1947, ako malé, pozdnohradištné opevnenie bez trvalého osídlenia, ktoré chránilo prístup na Vel'ký vrch (Petrovský-Šichman 1964, 71). Prvá sondáž bola na lokalite vykonaná v roku 1982 pracovníkmi Považského múzea v Žiline s kolegami z AÚ ČSAV (Moravčík 1991). Identifikovali malú hornú plošinu s dvoma valovými opevneniami, jedným nevýrazným na okraji vrcholovej plošiny a druhým sledujúcim pätu kóty. Sondy vykopali na viacerých miestach hornej plošiny a v priekope za dolným valom, ich plán však nebol publikovaný. V sonde umiestnenej v telese horného valu našli tvrdo vypálené, tmavohnedé, čiernohnedé až čierne črepy z nádob s vysokými vyhnutými a šikmo zrezanými okraj$\mathrm{mi}$, zdobené nízkymi vlnovkami a pravidelnými ryhami (Moravč́́k 1991, 14, tab. IV: 1-8, 11). Okrem toho sa v ich blízkosti nachádzali aj uhlíky a drobné kúsky mazanice. Posledné terénne aktivity pred terajším výskumom vykonali J. Malec a R. Huszár,

\footnotetext{
1 Táto práca bola podporovaná Agentúrou na podporu výskumu a vývoja na základe Zmluvy č. APVV-15-0330. 3D rekonštrukcie sú vytvorené pod záštitou projektov ITMS 26220120059 a ITMS 26210120031.
} 


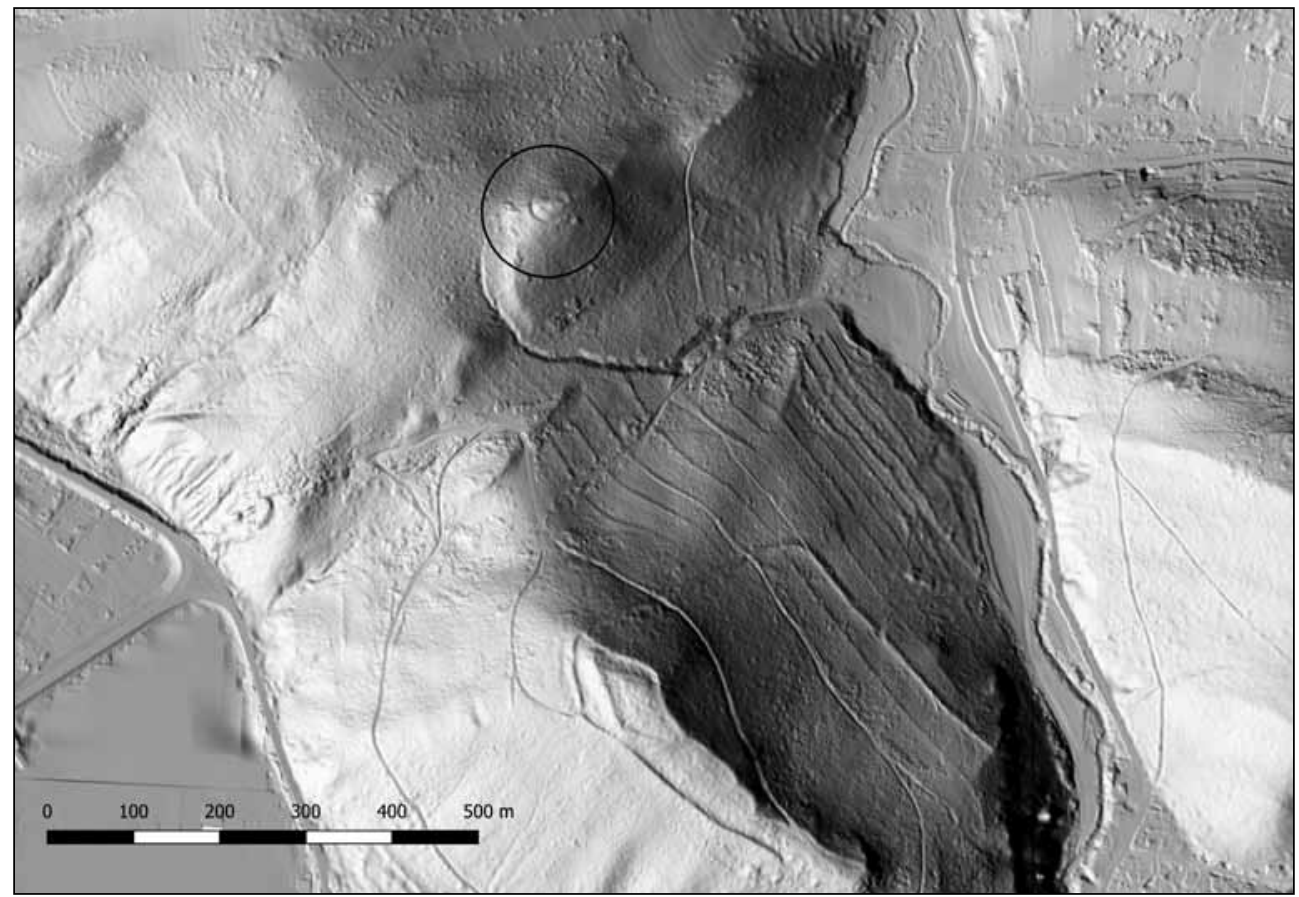

Obr. 1. Divinka - Divina. Lidarová snímka okolia hrádku. Skúmaná lokalita je zakrúžkovaná.

ktorí lokalitu zamerali a vytvorili schematický plán (Malec 2010, obr. 1). Na celej ploche hrádku nezistili stopy murovanej architektúry či dôkaz staršieho osídlenia. Opierajúc sa o Moravčíkove poznatky predpokladali, že táto výhodná strategická poloha bola využitá v 12. až 13. stor. na vybudovanie drevozemného hrádku (Malec 2010, 122).

\section{NÁLEZOVÁ SITUÁCIA}

V rokoch 2018-2019 prebehol za spolupráce Archeologického ústavu SAV Nitra a Považského Múzea v Żiline na lokalite zistovací výskum s cielom geodeticky a geofyzikálne zamerat’ polohu a následne archeologickými metódami zistit rozsah osídlenia, štruktúru opevnenia a upresnit jeho datovanie. Skúmaná lokalita leží na kuželovitom vŕšku výrazne odčlenenom od okolitého terénu (obr. 1). Na ňom je predížená dvojstupňová oválna plošina, z ktorej je možné vyčlenit dolnú a hornú terasu, z troch strán chránenú strmým svahom, prudko spadajúcim do údolia (obr. 2). Jediná schodná prístupová cesta $\mathrm{k}$ tejto vrcholovej plošine viedla po šiji z juhozápadného smeru. Na tomto mieste bola vybudovaná hradba dlhá približne $30 \mathrm{~m}$, vo forme valu dodnes viditelne zachovaná $\mathrm{v}$ teréne, rovnako ako vnútorná priekopa. $\mathrm{V}$ priestore vonkajšieho valu, kde nebolo pochybností o jeho lokalizácii, sme umiestnili sondu, ktorá ho pretínala spolu s priekopou a priestorom pred ním. V tej istej línií boli na vrcholovej plošine vyhíbené dve sondy, ktoré mali za úlohu zdokumentovat' vertikálny prierez lokality a identifikovat' prípadné objekty. Potvrdili druhú obrannú líniu na hrane hlavného kužela lokality, a taktiež palisádový žlab v blízkosti najvyššie položeného bodu lokality. Zistovacie sondy sa následne rozširovali $\mathrm{v}$ miestach, kde sa nachádzala vyššia koncentrácia keramiky, alebo kde sa očakávali sídliskové objekty, ktoré sa však s výnimkou jedného oválneho zahíbeného objektu nedochovali. Počas druhej sezóny sa skúmaný priestor v okolí druhej fortifikačnej línie ešte rozšíril na finálnych $5 \mathrm{~m}$, palisádová priekopa sa prerezala ešte jednou $1 \mathrm{~m}$ širokou sondou. Doklady osídlenia sa nachádzali len v blízkosti maximálne pät metrov od druhej línie opevnenia. Na zvyšku vrcholovej plošiny bolo štrkovité podložie pomerne plytko, v híbke asi $25-30 \mathrm{~cm}$, prevrstvené len hnedou hlinou a humusovou vrstvičkou. Na najvyššom bode hrádku, v mieste kde je umiestnená výšková kóta, bola podložná skala ešte plytšie, v híbke asi $10-15 \mathrm{~cm}$. S výnimkou palisádového žlabu sa tu nenachádzali staršie doklady antropogénnej činnosti, len štyri jamy po triangulačnej veži, ktorá tu stála minimálne do roku 1955, kedže z nej Petrovský-Šichman fotografoval vonkajší val a Vel'ký vrch (Petrovský-Šichman 1955, 13).

Predpokladaná veža samotného hrádku nebola potvrdená. O existencii stavby nezachytenej archeologickým výskumom tak svedčí len spomínaný hrotitý žlab vysekaný do podložia 


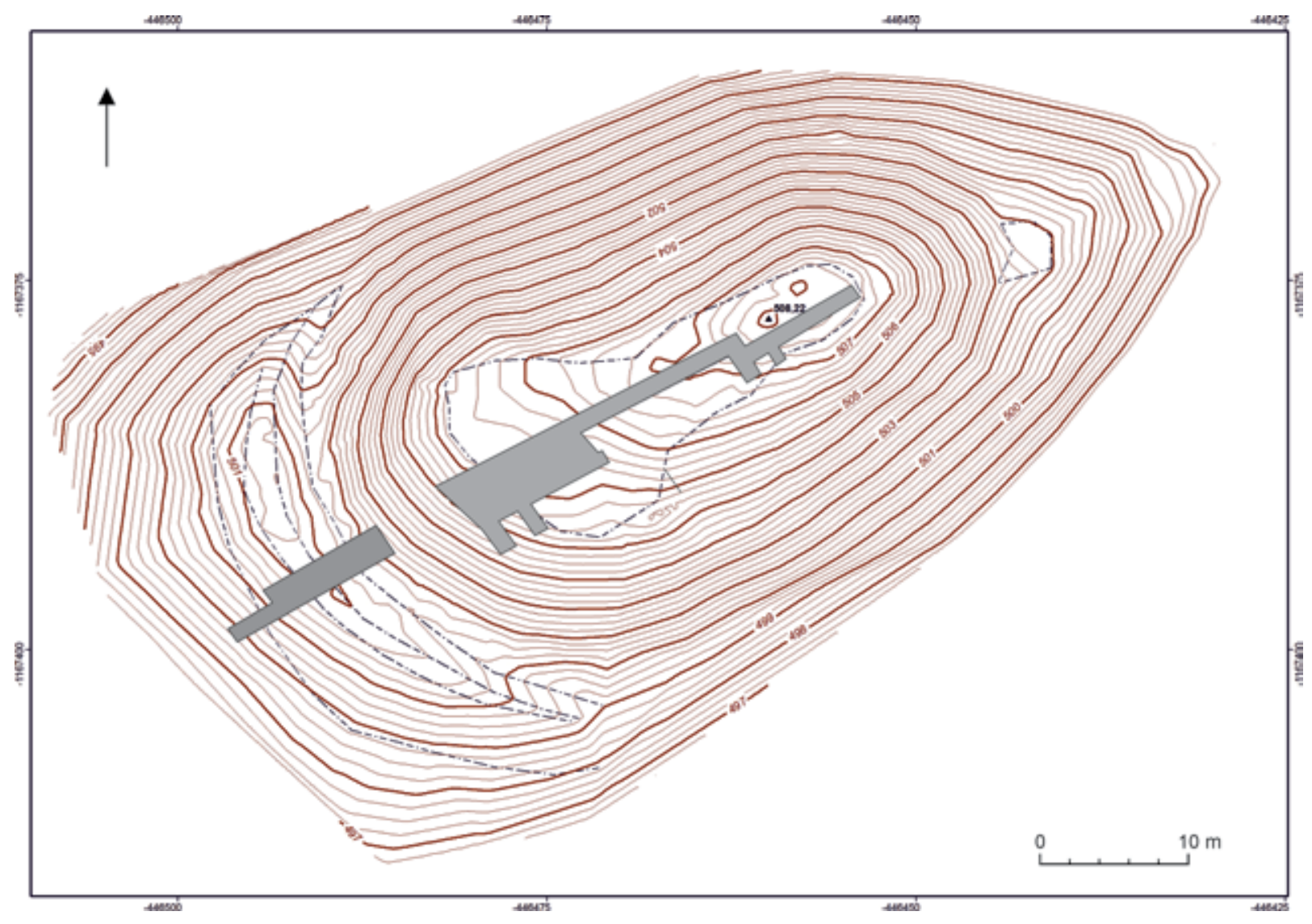

Obr. 2. Divinka - Divina, poloha Hradisko. Plán lokality s vyznačeným priestorom výskumu (sivá farba). Zameranie M. Bartík.

na päte skalnatej homole na vrchole plošiny. Celá situácia na vrchole kopca bola zrejme značne porušená aktivitami v 20. stor., kedy tu ludia z okolia podla slov pamätníkov často chodievali na pikniky, pásli tu kravy a na Turíce usporadúvali oslavy spojené s pálením vatier. Detektorový prieskum plošiny, ktorý bol vykonaný v spolupráci s OZ Hradiská v prvých dňoch výskumu, priniesol najmä súbor stredovekých železných hrotov šípov a menšie množstvo súdobých predmetov dennej potreby.

\section{Vonkajšie opevnenie}

Vonkajší val chrániaci prístupovú cestu od juhozápadu bol najvyšší v jeho severnej časti a postupne sa znižoval smerom na juh, kde sa plynulo pripájal k päte kužela kopca. Val aj vnútorná priekopa boli preskúmané $13 \mathrm{~m}$ dlhou a 1-2 $\mathrm{m}$ širokou sondou (obr. 3). Na základe odhalených vrstiev nebolo možné jednoznačne určit šírku hradby. Hoci z vnútornej strany je jej ohraničenie jasné, v mieste výskumu stavitelia využili na zasadenie líca v tejto časti výbežok podložnej skaly. Celé teleso sa po zániku lokality zrejme plynule zosunulo dolu svahom. Hlavnú masu tvorila hnedá lesná hlinitá pôda, ktorá sa okrem väčšieho objemu kameňov nedala odlísit od vrchnej vrstvy na zvyšku lokality. Len vo vnútri valu bola odhalená drevená lícna konštrukcia, v podobe $2 \mathrm{~m}$ širokej a $10-15 \mathrm{~cm}$ hrubej súvislej vrstvy spálených kusov driev ležiacej na hlinitej vrstve sýtej červenej farby širokej 3 až $4 \mathrm{~m}$ a hrubej 0,3 až $1 \mathrm{~m}$. Archeobotanicky boli v uhlíkovej vrstve rozoznané dve dreviny: dub (Quercus sp.) a slivka (Prunus sp.). ${ }^{2}$ Je možné predpokladat', že vonkajšie líce tohto valu bolo vyrobené $\mathrm{z}$ masívnejších dubových súčastí doplnených $\mathrm{v}$ niektorých častiach výpletom zo slivkových prútov. Nie je možné vylúčit ani prípadné spevnenie nasucho kladenými kameňmi, ktoré sa po zániku tohto objektu skotúlali dolu svahom, a nebolo tak možné identifikovat súvislú štruktúru. Túto hypotézu môže potvrdzovat aj fakt, že pomerne väčšie množstvo kameňov sa nachádzalo v predpolí valu v nižšej časti svahu, než $\mathrm{v}$ priestore $\mathrm{v}$ bezprostrednej blízkosti zhoreného

2 Všetky archeobotanické vzorky z výskumu určila J. Mihályová, AÚ SAV Nitra. 


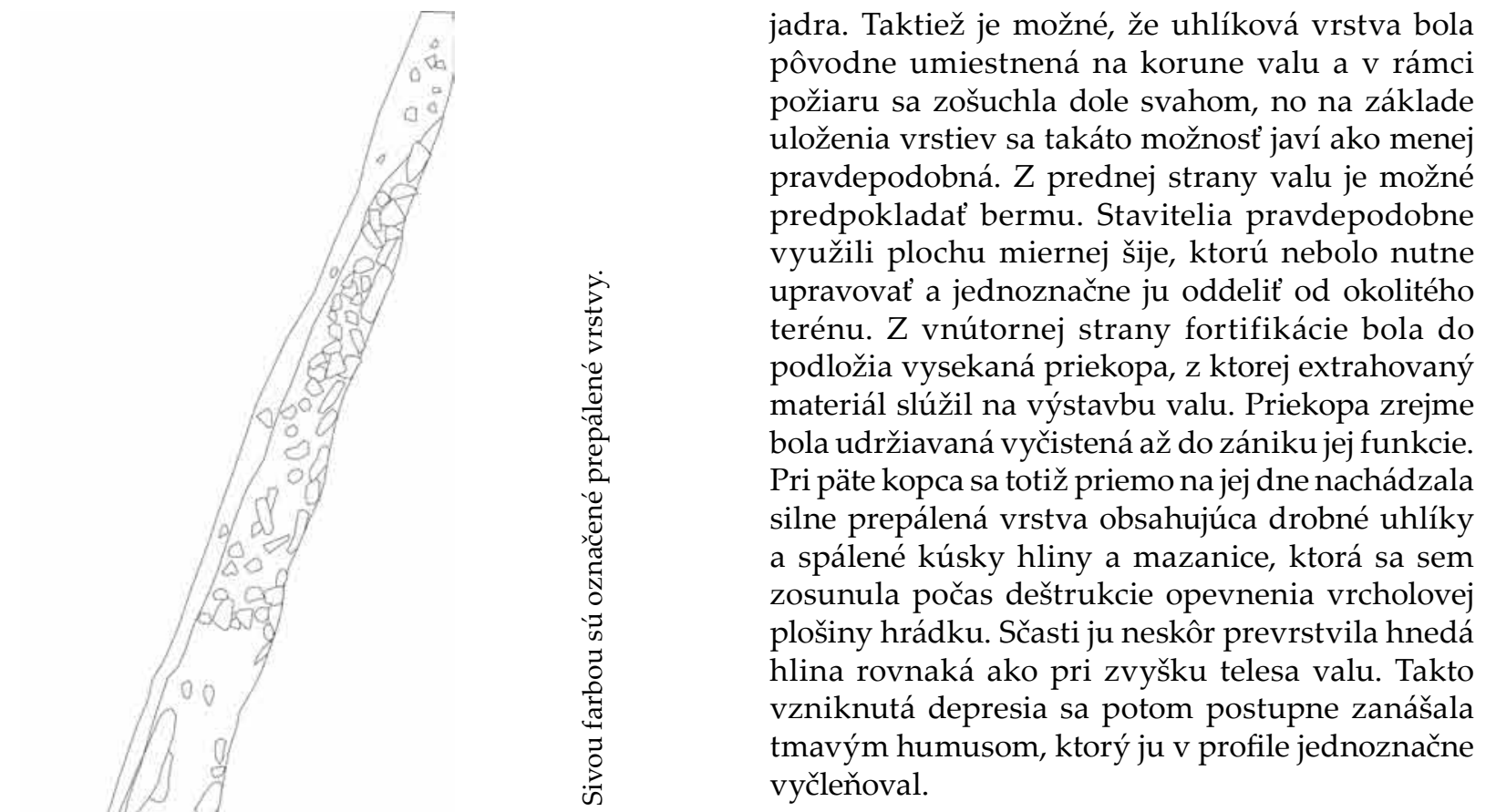

Dolná terasa

Od vnútornej priekopy vonkajšieho valového opevnenia terén prudko stúpa na čast’ označenú ako vrcholová plošina, členená na dve úrovne, hornú a dolnú terasu. Na juhozápadnom okraji dolnej terasy sa $\mathrm{v}$ osemdesiatych rokoch dal identifikovat pomerne nevýrazný valovitý útvar, $\mathrm{v}$ súčasnosti takmer neidentifikovatelný. Tento útvar sa preskúmal, tak ako celá vrcholová plošina, sondou v šírke $1 \mathrm{~m}$, ktorá slúžila na zorientovanie sa $\mathrm{v}$ stratigrafických situáciách. $\mathrm{V}$ profile sondy, ktorá tento útvar pretínala (obr. 4), bola jasne odlíšitelná výrazná prepálená červená hlina tvoriaca výplň tejto fortifikácie, v ktorej sa črtali tmavšie vrstvy spálenej vnútornej drevenej konštrukcie. Sonda sa následne rozšírila do šírky, zahŕňajúc samotné valové teleso, ako aj priestor pred ním a za ním (obr. 5). Približne jeden meter pred koncom telesa valu boli zachytené dná troch kolových jám, črtajúcich sa už len ako flaky spálenej čiernej farby v odstupoch $1 \mathrm{~m}$. Vo vnútri násypu, zachovaného v maximálnej hrúbke $80 \mathrm{~cm}$, boli približne do polovice jeho výšky zapustené dve kolové jamy v rozostupe $2 \mathrm{~m}$, datované aj rádiouhlíkovou metódou. $Z$ vnútornej strany bol val ohraničený žliabku podobným útvarom. Tento priestor vznikol pri úprave pôvodného terénu, z ktorého čast’ odkopali a do vytvoreného priestoru postavili koly podopreté priečnymi brvnami, ktoré následne zasypali (obr. 6). Po deštrukcii hradby sa prázdny priestor po koloch sčasti zosunul do seba a čiastočne ho zaplnili pozostatky hlineného 


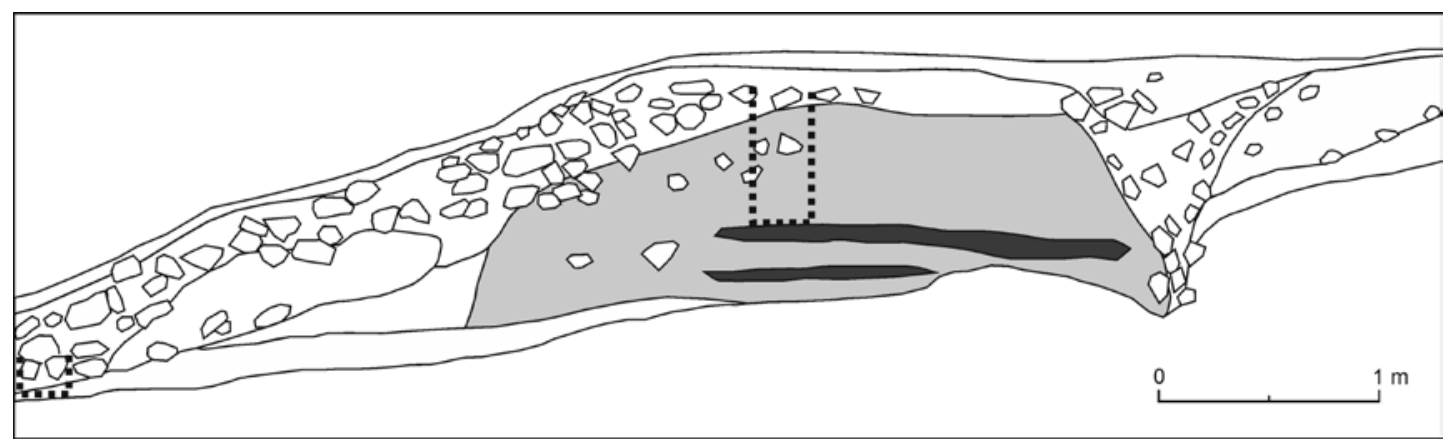

Obr. 4. Divinka - Divina, poloha Hradisko. Profil rezu druhou líniou opevnenia hrádku. Sivou farbou sú označené prepálené vrstvy, bodkovanými čiarami sú vyznačené kolové jamy premietnuté na profil.

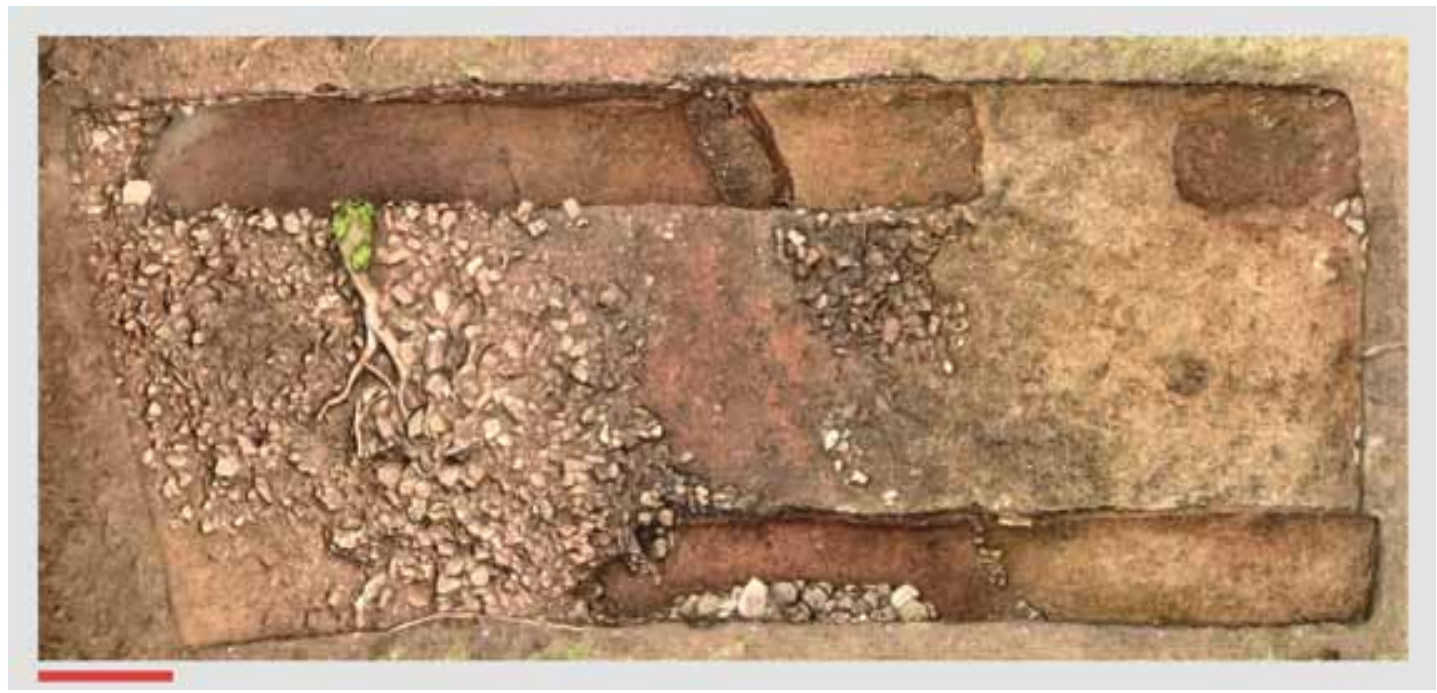

Obr. 5. Divinka - Divina, poloha Hradisko. Fotogrametrický plán sondy pretínajúcej druhú líniu opevnenia hrádku po prvotnom rozšírení. Autori G. Fusek a A. Arpáš.

jadra, vytvoriac tak $\mathrm{v}$ profile vrstvu $\mathrm{v}$ tvare písmena V. Vzorky z kolových jám z vnútra jadra valu pochádzali z buka (Fagus sylvatica), jelše (Alnus sp.) a brezy (Betula sp.). Celú situáciu prekrývala súvislá kamenná vrstva.

Konštrukcia druhej línie fortifikácie je na základe nálezových situácií identifikovaná nasledovne (obr. 7). Samotná vonkajšia hrana dolnej terasy bola zo statických dôvodov pred výstavbou upravená. Do svahu nabili krátke koly vo vzdialenosti $1 \mathrm{~m}$ od seba, medzi ktoré horizontálne uložili nízku organickú zábranu z dosiek alebo výpletu tenšími konármi. Priestor medzi zábranou a hranou zarovnali, slúžil ako berma. Na tento priestor následne postavili hradbu škrupinovej konštrukcie, ktorej teleso tvoril násyp z drevených roštov zasypaných hlinou. Z vnútornej strany ju zadržiavala palisáda osadená do plytkého žliabku, z vonkajšej strany násyp obložili väčšími kameňmi. Na vrchu sa nachdázala drevená predprseň, ktorá pozostávala z kolov zapustených $\mathrm{v}$ dvojmetrových rozostupoch. Priestor medzi nimi vyplńali vodorovné dosky či brvná zasadené do žliabkov v koloch. Ochodzu zrejme vydláždili menšími kameňmi, nájdenými na povrchu zhorenej hradby.

V d’alšom priestore dolnej terasy sa očakávali stopy osídlenia, avšak odkrytý bol len jeden zahíbený objekt (obr. 8). Išlo o oválnu, takmer okrúhlu jamu s rozmermi asi 1,1 x 1,2 m, so zachytenou híbkou $20 \mathrm{~cm}$. Vypíňala ju prepálená červená hlina a drobné uhlíky, spolu s malým počtom kameňov, ktoré netvorili žiadnu súvislú štruktúru. Na základe toho je možné uvažovat, že išlo o jednoduché otvorené ohnisko. Nie je však možné jednoznačne povedat', či sa nachádzalo vo vnútri stavby alebo v exteriéri. Obdobný objekt bol odkrytý na sídlisku v Beckove, datovaný do vrcholného stredoveku (Hanuliak 2018, 123, tab. I). Na preskúmanej ploche neboli jednoznačne identifikované žiadne pozostatky po prípadnej podmurovke obytných budov, preto je 


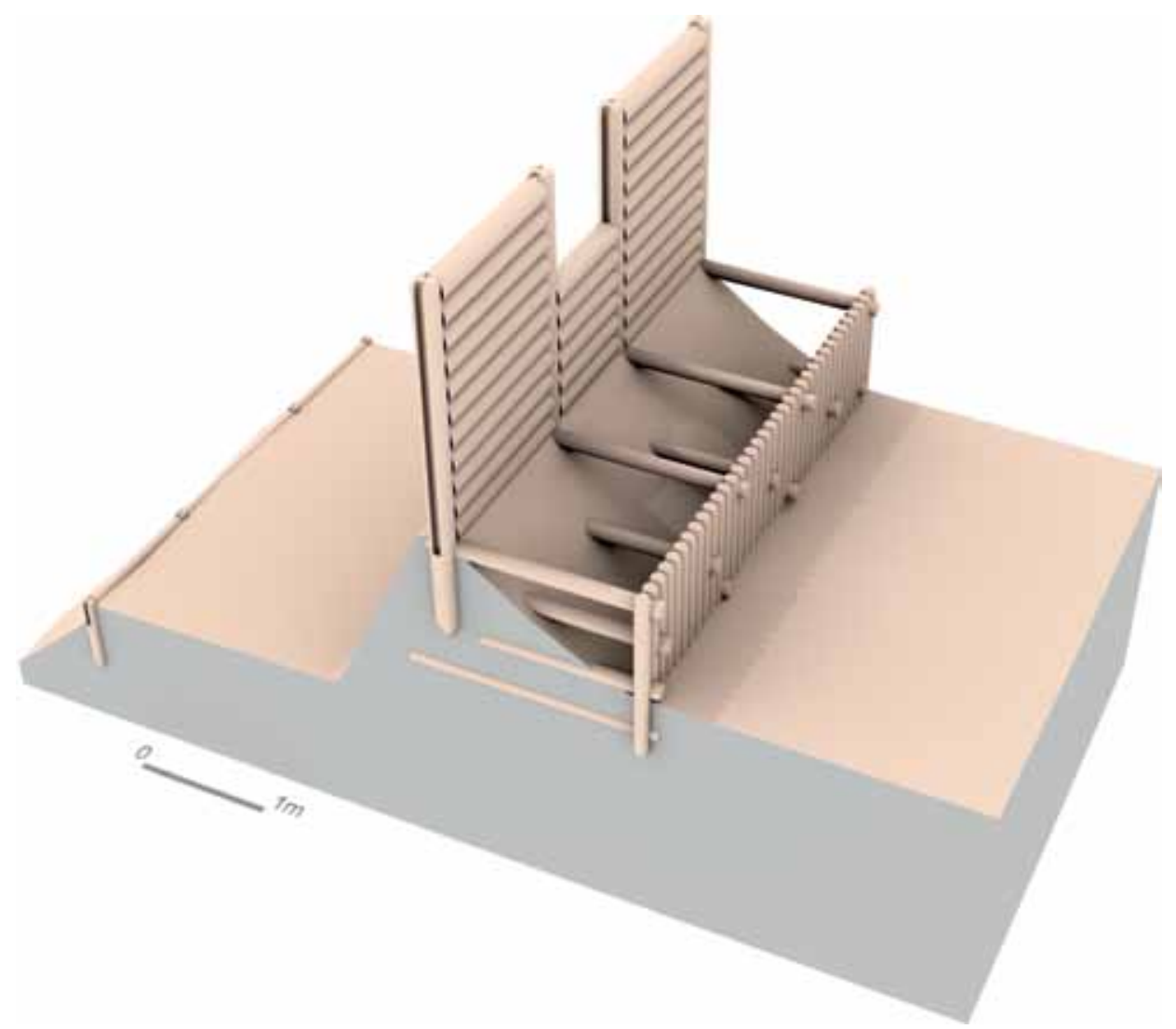

Obr. 6. Divinka - Divina, poloha Hradisko. Vizuálna rekonštrukcia techniky výstavby druhej línie fortifikácie pred úplným zasypaním ochodze. Autor rekonštrukcie A. Arpáš.

možné sa domnievat', že stavby, ktoré tu stáli boli zruby. Preskúmané ohnisko tak mohlo, ale aj nemuselo byt súčastou stavebného objektu. V kultúrnej vrstve na dolnej plošine sa našiel len minimálny počet keramických zlomkov, ktoré sa koncentrovali v prevažnej väčšine v blízkosti terajšej hrany terasy, čo taktiež poukazuje na absenciu vyhíbení zachycujúcich splachovaný materiál, ktorý sa tak zastavil až na deštrukcii hradby. Tomuto predpokladu zodpovedá aj vel'mi malý počet črepov v priestore vonkajšej fortifikácie.

\section{Horná terasa}

Na päte hornej terasy, tesne pod homôlkou, na ktorej je osadená výšková kóta, bol odkrytý do skaly vysekaný priekopovitý útvar, žlab s hrotitým dnom, s maximálnou šírkou $1 \mathrm{~m}$ a híbkou asi $30 \mathrm{~cm}$. Jeho výplň bola tmavá, humusovitá s vysokým počtom drobnejších kameňov a mazanice. Najvýraznejší bol v severozápadnej časti, smerom po svahu, na juhovýchod sa postupne plynule strácal. Oddeloval najvyšší bod lokality, na ktorom stála predpokladaná vežovitá stavba.
K nej sa dalo dostat' len úzkym priechodom medzi žlabom, v ktorom bola osadená palisáda a strmým svahom, ktorý mohol byt prípadne bránený iným provizórnym fortifikačným prvkom. Ked’že žlab sa strácal plynule a v mieste jeho ukončenia neboli identifikované žiadne iné vyhĺbené objekty, ktoré by mohli naznačovat nejakú pevnú štruktúru, nepredpokladáme, že by sa v tomto mieste nachádzala nejaká trvalá brána. Je tiež možné uvažovat', že takáto forma opevnenia, či skôr ohradenia, bola $\mathrm{v}$ prípade existencie dalších dvoch fortifikačných línií zbytočná. Mohlo teda íst' len o dočasný prvok, ktorý bol potrebný na aspoň čiastočnú ochranu vežovitej stavby pred, alebo aj počas výstavby vonkajšieho opevnenia.

Analogická situácia bola odkrytá na vrcholnostredovekom hrádku v Pezinku, časti Cajla, nazvanom Starý zámok II (Farkaš 2015, 267, 268), kde prístupovú cestu k najvyššiemu bodu hrádku sčasti prehradzoval žlab vysekaný do skaly, tak isto hlboký asi $30 \mathrm{~cm}$. Rovnako ako v Divinke, ani na tejto lokalite neobkružovala priekopa celú vrcholovú homolu a vzniknutý $1 \mathrm{~m}$ široký priestor medzi žlabom a prudkým neschodným zrázom slúžil ako vstup na osídlenú vrcholovú plošinu. 


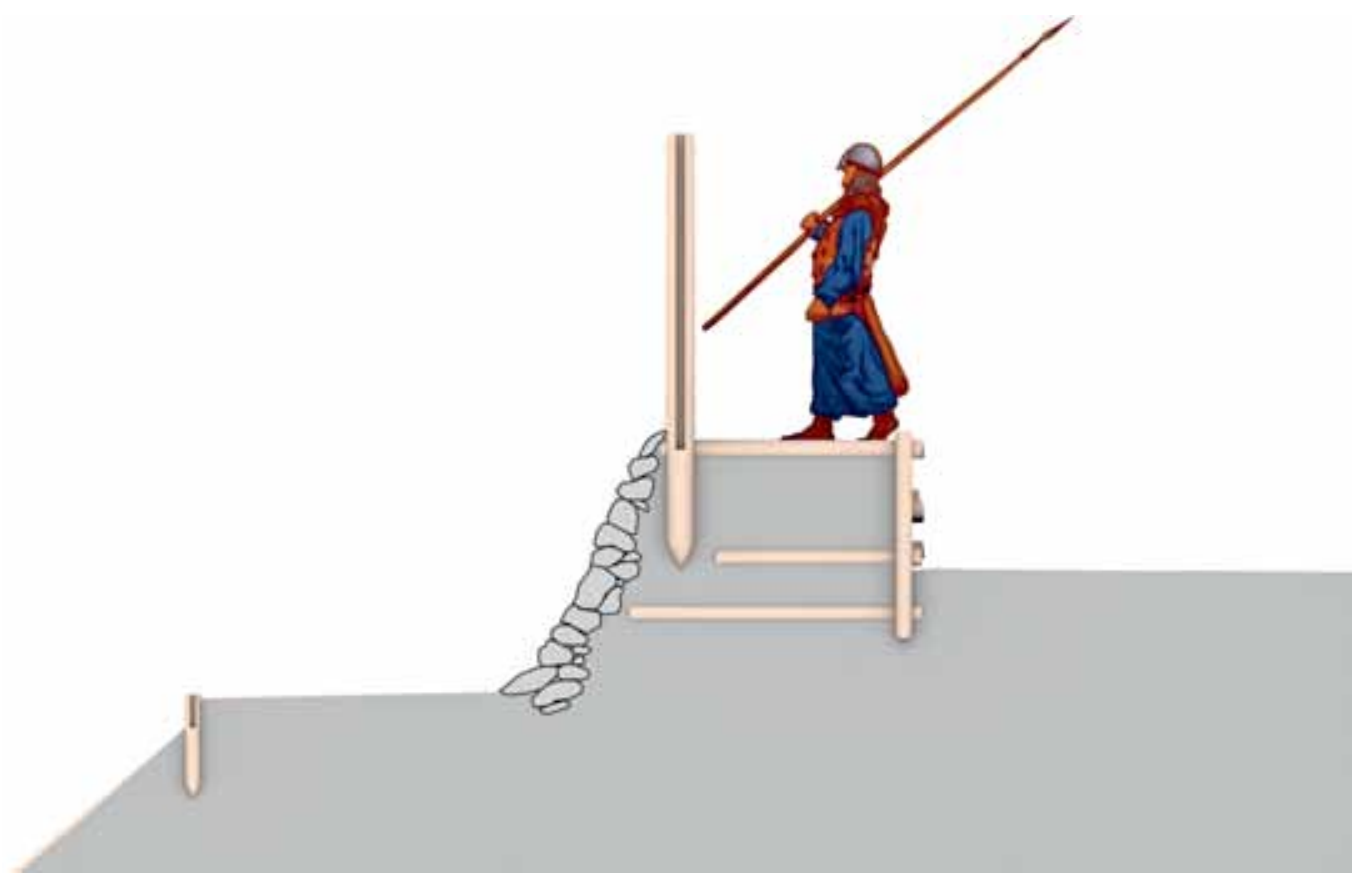

Obr. 7. Divinka - Divina, poloha Hradisko. Vizuálna rekonštrukcia profilu druhej línie opevnenia hrádku. Autor rekonštrukcie A. Arpáš.

Na najvyššom bode lokality s umiestneným kótovacím kameňom sa pravdepodobne nachádzala hlavná obytná vežovitá stavba. V 20. stor. presne na tomto mieste existovala drevená triangulačná veža, po ktorej sa počas výskumu našli štyri hlboké jamy vysekané do podložia, na dne ktorých sa nachádzali masívne moderné klince.

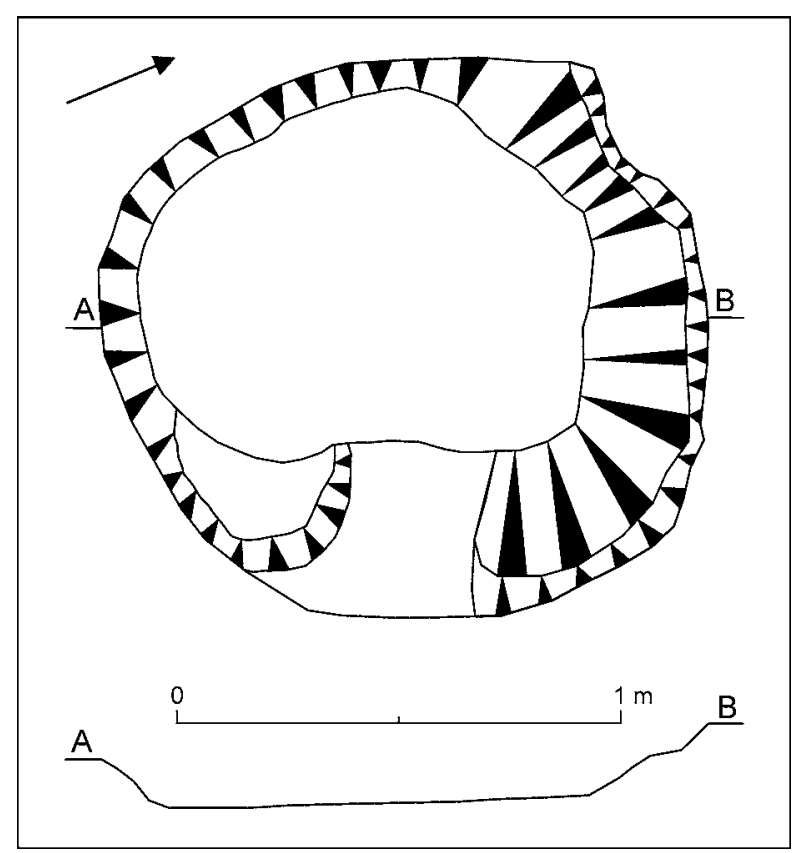

Obr. 8. Divinka - Divina, poloha Hradisko. Ohnisko preskúmané na dolnej terase vrcholovej plošiny.
O existencii vežovitej stavby je možné uvažovat’ na základe analogických lokalít (Ruttkay 1992, 256, 257). Konštrukcia takýchto stavieb bývala murovaná, drevená, alebo kombináciou oboch týchto stavebných techník. Vo výplni žlabu, ktorý zrejme slúžil na vyčlenenie či ochranu tejto stavby, sa nachádzal vel'ký počet mazaníc rôznych rozmerov, niektoré z nich s odtlačkami rovného štiepaného dreva a neobsahovala väčšie či stredne vel'ké kamene, ktoré by boli vhodné na murovanie. $Z$ toho je možné predpokladat', že veža na Hradisku v Divinke mala drevenú konštrukciu s vypletanými či doštenými stenami, omietnutými hlinou. Jej rozmery sú determinované vel'kostou terasy, na ktorej stála a dížka jednej jej strany nemohla presiahnut $3 \mathrm{~m}$.

\section{HNUTEL’NÉ NÁLEZY}

Z vrcholovej plošiny hradiska sa počas výskumu a detektorového prieskumu získal súbor siedmich kompletných hrotov šípov (obr. 9: 2-8) a jeden odlomený koniec hrotu šípu (obr. 9: 1). Všetky tieto artefakty je možné zaradit do jedného typu hrotov s úzkym šidlovitým telom kvadratického prierezu, s miernym zúžením $v$ jeho dolnej tretine a plynulo prechádzajúcim do kŕčku taktiež štvorhranného prierezu, ktorý je schodovito odčlenený od upevnenia na drievce tŕňom, označeného ako typ C. VIII.1.Za (Holešćák 2019, mapa 15: c; tab. XV: 2-4). 

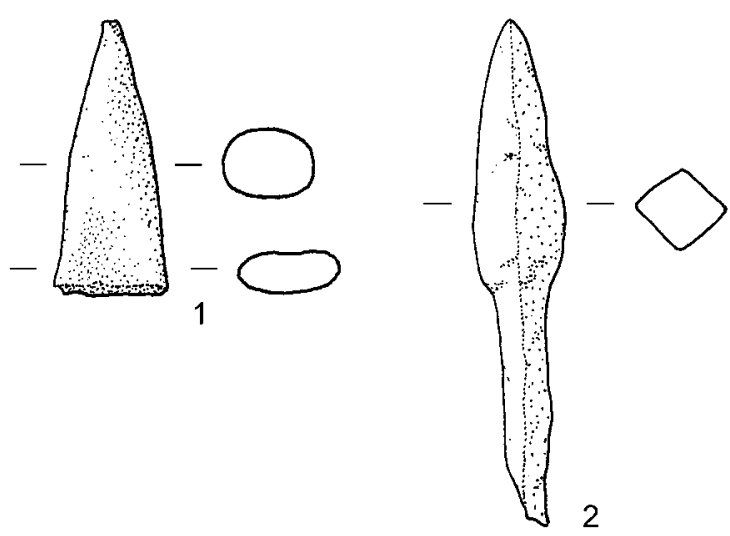

0
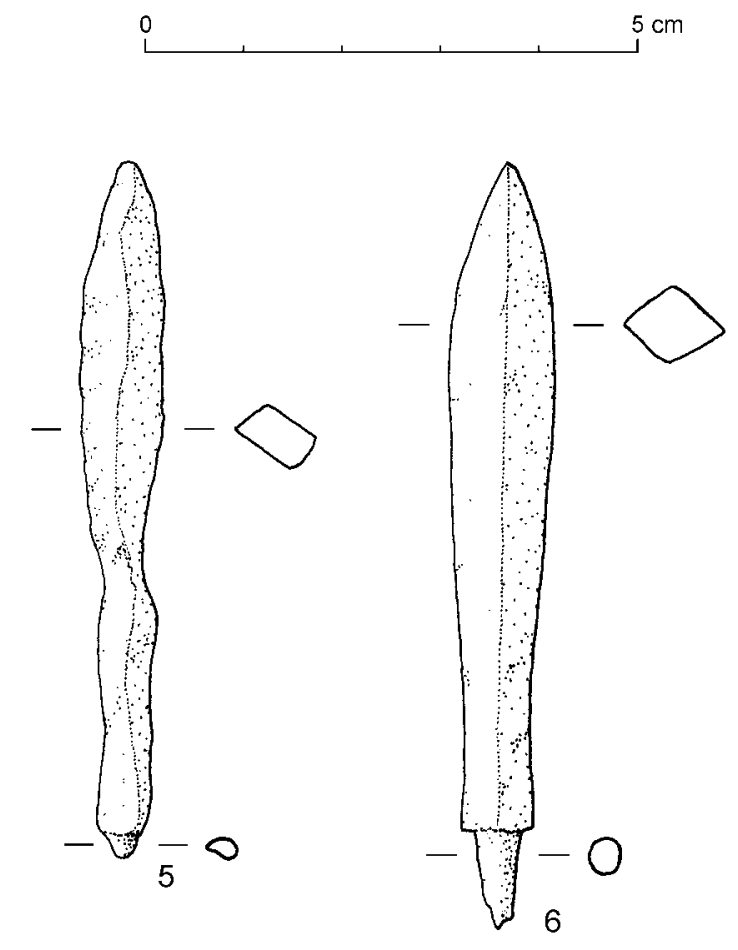

$5 \mathrm{~cm}$
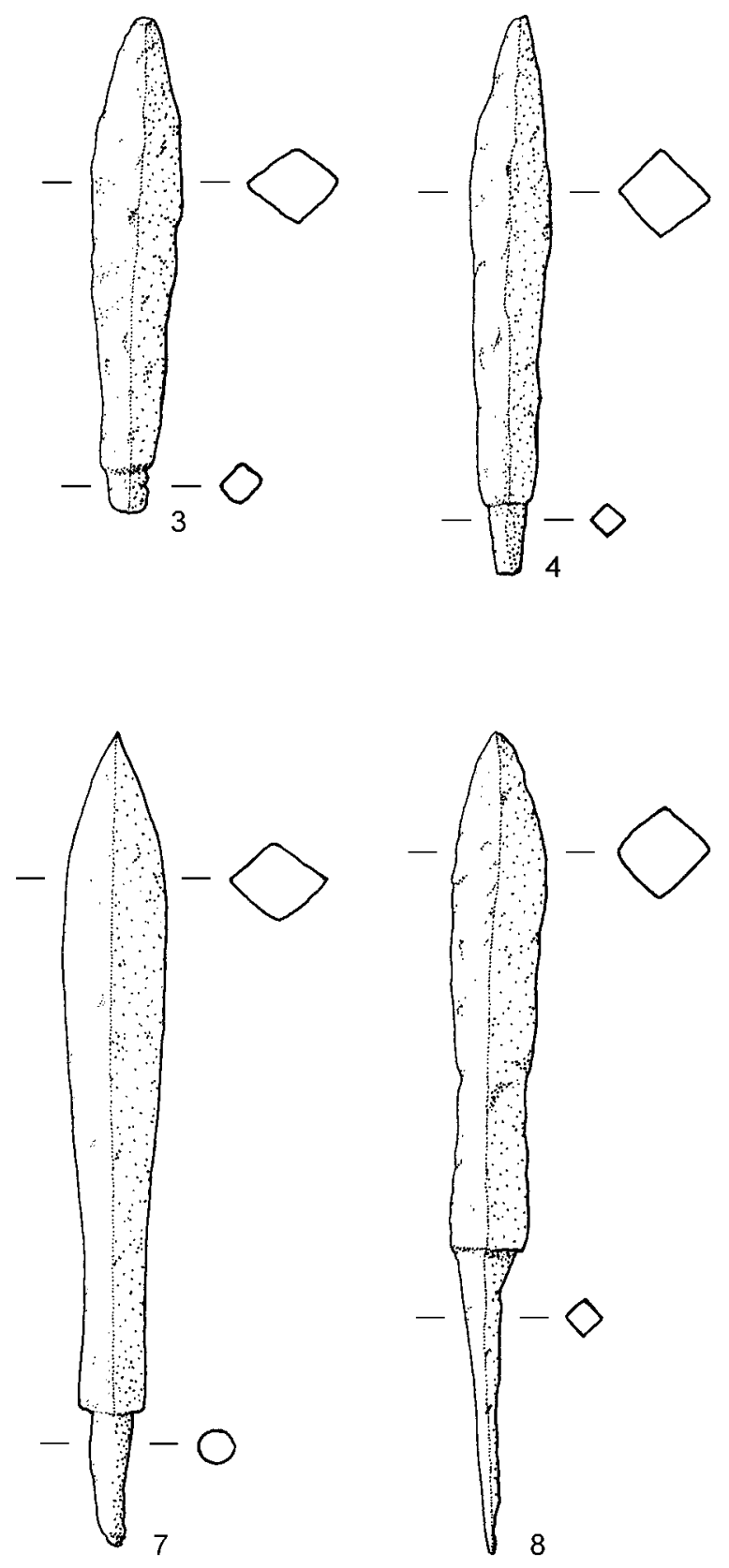

Obr. 9. Divinka - Divina, poloha Hradisko. Železné hroty šípov z lokality.

Na základe prierezu tŕňa je ich možné rozdelit’ do dvoch skupín po troch kusoch, s oválnym (obr. 9: 5-7) a kvadratickým (obr. 9: 3, 4, 8) prierezom. $\mathrm{V}$ jednom prípade bol tŕň odlomený, a tak nebolo možné zistit tvar prierezu (obr. 9: 2). Prierez tŕňa však na základe súčasného stavu bádania neurčuje chronologickú či typologickú odlišnost'. Najpravdepodobnejšie vysvetlenie rôzneho tvaru prierezu je špecifickost kováča a suroviny, ktorú použil. Analogické typy hrotov šípov sú charakteristické pre územie strednej, stredovýchodnej a juhový- chodnej Európy, datované sú do 13.-14. stor. Na území Slovenska sa hojne vyskytujú na opevnených polohách v Malých Karpatoch, ako aj na hradoch na strednom a východnom Slovensku (Holeščák 2019, 56, s lit.). Na základe rozmerov a najmä hmotnosti je možné uvažovat', že masívne hroty tohto typu boli používané do kuše, subtílnost' hrotov z Divinky však poukazuje skôr na hroty šípov vystrel'ovaných z luku.

Analogické hroty šípov boli nájdené aj v blízkosti skúmanej lokality, jeden nepublikovaný 


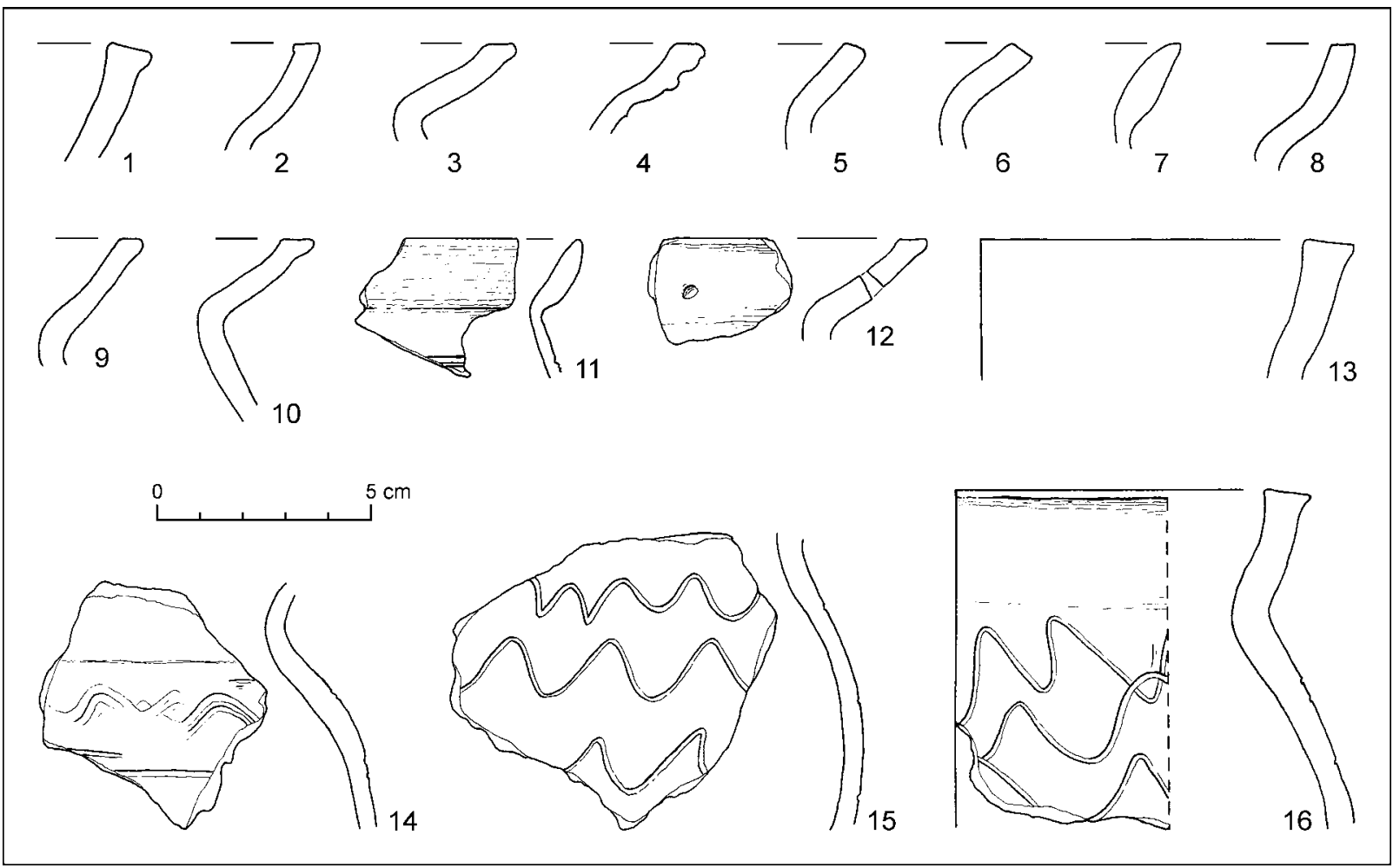

Obr. 10. Divinka - Divina, poloha Hradisko. Výber keramických črepov z lokality.

exemplár sa v roku 2019 našiel v predpolí hradiska na Vel'kom vrchu. Podla opisu sa obdobný typ, avšak bez grafického vyobrazenia, našiel na primárne pravekej lokalite Malé Ostré v Lopušných Pažitiach (Šedo 1980, 203). Od Hradiska je vzdialená len $10 \mathrm{~km}$ vzdušnou čiarou, nachádza sa na opačnej strane rieky Kysuce v blízkosti známej stredovekej lokality Radola. Zo samotného Malého Ostrého však nepochádzajú iné takto datované nálezy a podla O. Šeda je z toho dôvodu tento hrot šípu dokladom len ojedinelej prítomnosti človeka vo vrcholnom stredoveku. Jeho závery už nie je možné overit', ked'že značná čast polohy je zničená kameňolomom. Nepublikovaný analogický hrot šípu sa nachádza v depozitári Považského Múzea v Žiline, pochádza zo Súlova. Pravdepodobne ide o exemplár spomínaný Petrovským-Šichmanom $(1964,107)$, údajne nájdený na terase pod hradom. Bez bližších nálezových okolností však nie je možné o jeho datovaní napísat viac.

Tento typ hrotov šípov sa neobmedzuje na územie Slovenska či Uhorska, ale je charakteristický pre širší geografický okruh. Z územia Českej republiky je z hladiska geografickej blízkosti a kultúrnej spriaznenosti dôležité spomenút napríklad opevnenie v Bílej (Kouřil/Prix 1995, obr. 3: 2), moravsko-sliezsky pohraničný hrad Freudenštejn (Kouřil 1997, obr. 4: 1-6), či hrad na Hrádníkách pri
Zářeckej Lhote (Vích 2016, obr. 22). Hrádok v Hrádníkoch bol rovnako ako ten v Divinke osídlený krátko a mal predovšetkým vojenský charakter (Vích 2016, 160).

Na lokalite Hradisko boli nájdené aj črepy keramických nádob, ktoré je možné porovnat s okolitými vrcholnostredovekými lokalitami v okolí Žiliny (Vanglová 2010; Vojteček 2015). Keramický materiál pochádza prevažne z obtáčaných hrncovitých nádob s lievitkovite nasadeným ústím a vodorovne (obr. 10: 2-4, 8-10, 12) či šikmo zrezaným (obr. 10: 1, 5, 6, 16), oblým (obr. 10: 7, 11), či ojedinele so zložito profilovaným (obr. 10: 4) okrajom. Ústie je pod okrajom bud' mierne vypuklé, alebo s jemným náznakom lišty. Hrnce majú najčastejšie hrúbku steny $5-7 \mathrm{~mm}$, ojedinele sa vyskytujú aj tenkostenné exempláre. $V$ keramickom materiáli sa tiež objavujú črepy z tiel zásobníc. $Z$ výzdoby sa najčastejšie vyskytuje jednoduchá viacnásobná vlnovka (obr. 10: 15, 16) a v menšej miere hrebeňová vlnovka kombinovaná s vodorovnou ryhou (obr. 10: 14). Na jednom exemplári sa nachádza reparačný otvor (obr. 10: 12). Podla ty pológie T. Vanglovej v spracovanom súbore prevažujú vyklopené zrezané okraje typu O I ca 6 (Vanglová 2010, tab. XVII: 20-25). Ich analógie sa okrem Hradiska nachádzajú aj v Nededzi, zaniknutej dedine na ploche pod automobilkou KIA (Vanglová 2010, 103, 104), datovanou do 
12.-14. stor. (Bednár/Daňová 2008). Z tejto lokality pochádzajú aj d’alšie analógie $\mathrm{k}$ nálezom $\mathrm{z}$ Hradiska. Pri porovnaní s materiálom z Beluše, ktorý je datovaný medenou napodobeninou arabskej mince od druhej polovice 12. do prvej polovice 13. stor. je v Divinke - Divine možné pozorovat absenciu archaických foriem jednoducho vyhnutých ústí (Vlkolinská 2007, 52). Preto je možné uvažovat' o datovaní keramiky z Hradiska najskôr až do druhej polovice 13. stor. Obdobné typy archaickej keramiky, avšak už s výskytom vyvinutejších foriem analogických s črepmi z Hradiska sa našli aj na blízkej lokalite Bitarová (Vojteček 2015, 178, 179). O príklone zaradenia tejto keramiky do druhej polovice 13. stor. svedčí aj afinita našich nálezov s materiálnou kultúrou odkrytou v Beckove (Hanuliak 2007, 346, obr. 8: 2, 4, 6, 8), datovanou na základe typologickej analýzy podporenej mincou Přemysla Otakara II. z rokov 1251-1276 (Hanuliak 2018, 116, 139, 140). Ostatné nálezy z Považia, ktoré vykazujú podobnost’ s črepmi z Hradiska sú opät len rámcovo datované do 12.-13. stor. (Vanglová 2010, 111).

\section{RÁDIOUHLÍKOVÉ DATOVANIE}

Rádiouhlíkovou analýzou bolo možné datovat oba hlavné fortifikačné prvky na Hradisku, prvú aj druhú líniu opevnenia. Pri vonkajšom vale boli vzorky, ako už bolo uvedené, odobraté z prepálenej vrstvy, z dubového a slivkového dreva. Dubové drevo použité na konštrukciu je možné datovat' s viac než $95 \%$ pravdepodobnostou medzi roky 1164-1253 n. 1. (obr. 11). Slivkové drevo z tenkých niekol'koročných prútov vykazuje dva vrcholy datovacej krivky, pričom pravdepodobnejší, v ktorom sa nachádza medián, spadá do rozptylu rokov 1273-1306 n. 1. (obr. 12). Tieto dve vzorky nebolo možné kombinovat. Vzorka $z$ dubového dreva použitého na stavbu asi pochádzala $\mathrm{z}$ vnútorných letokruhov starého stromu, metodicky správne je hradbu datovat' tou najmladšou vzorkou, pochádzajúcou zo slivkových prútov.

$Z$ druhej línie opevnenia boli odobrané vzorky z dvoch kolových jám podporných stípov predprsne. $V$ jednom prípade bola určená vzorka bud' $\mathrm{z}$ bukového alebo brezového dreva, vykazujúca dva vrcholy s porovnatelnou pravdepodobnostou, medzi rokmi 1281-1328 a 1345-1395 (obr. 13). V druhej kolovej jame bol dobre datovatelný dvojročný borovicový konárik, s najvyššou pravdepodobnostou datovaný medzi roky 1255-1304 (obr. 14). Vzorky boli navzájom kombinovatel'né, takisto aj s mladšími uhlíkmi zo slivkového dreva z prvej línie opevnenia. Toto spojenie určuje

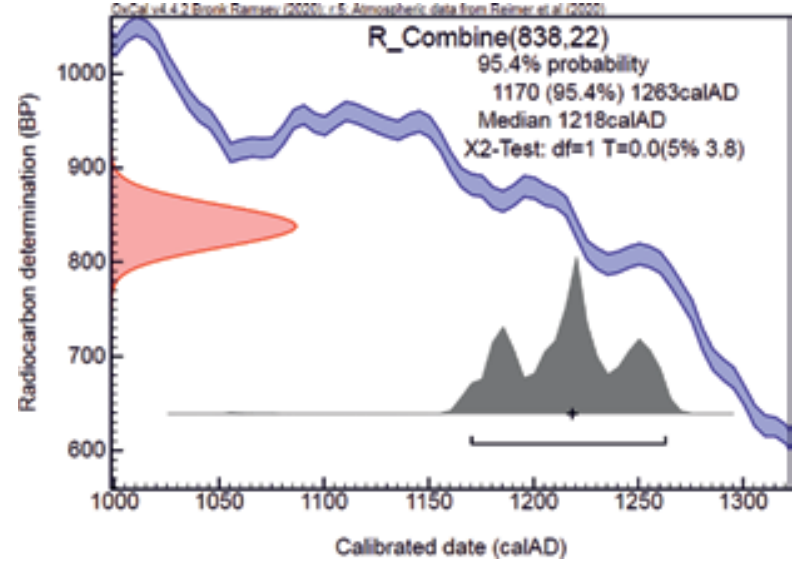

Obr. 11. Divinka - Divina, poloha Hradisko. Rádiouhlíkové datovanie dubového dreva z prvej línie fortifikácie.

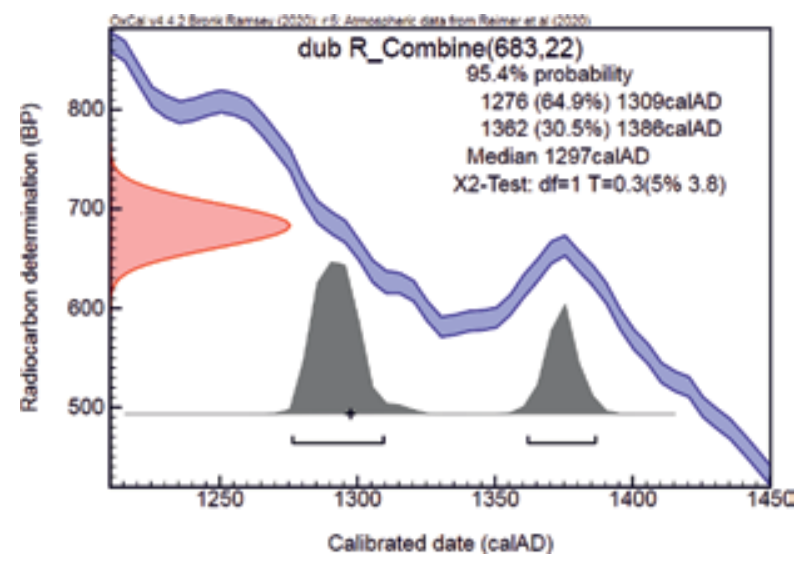

Obr. 12. Divinka - Divina, poloha Hradisko. Rádiouhlíkové datovanie slivkového dreva z prvej línie fortifikácie.

najpravdepodobnejšie obdobie výstavby hradiska medzi roky 1278-1304 (obr. 15).

$\mathrm{Z}$ priestoru vrcholovej plošiny sa $\mathrm{z}$ jednej z kolových jám a z priestoru vnútorného žlabu odobrali aj dve vzorky, ktorých rádiouhlíková metóda určila datovanie do obdobia okolo prelomu letopočtov. Z priestoru hradiska však nepochádzajú z doterajších výskumov predmety, ktoré by bolo možné priradit púchovskej kultúre, preto nie je možné vylúčit kontamináciu vzoriek. V jednej z nich podla archeobotanickej správy bola prítomná prímes zotletého lístia či kôry a $\mathrm{v}$ druhej prehorený kamienok, ktoré tomuto mohli napomôct'. Nie je však možné vylúčit ani krátkodobú prítomnost’ ludí púchovskej kultúry na tomto strategickom bode $\mathrm{v}$ bezprostrednej blízkosti známej lokality Vel'ký vrch, na ktorej bolo zaznamenané významné osídlenie $\mathrm{z}$ tohto obdobia (Fusek 2019, 222, 223), pozostatky ktorej sa sekundárne dostali do vrcholnostredovekých vrstiev. 


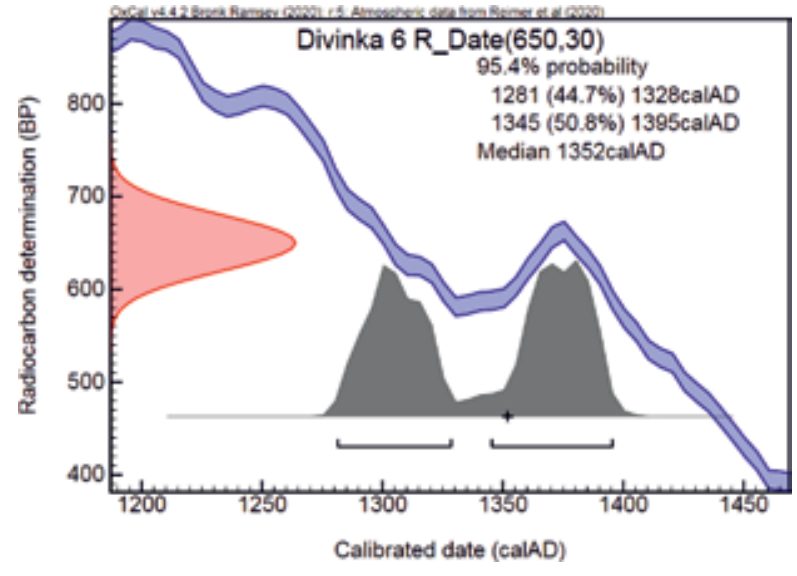

Obr. 13. Divinka - Divina, poloha Hradisko. Rádiouhlíkové datovanie vzorky z prvej kolovej jamy z druhej línie fortifikácie.

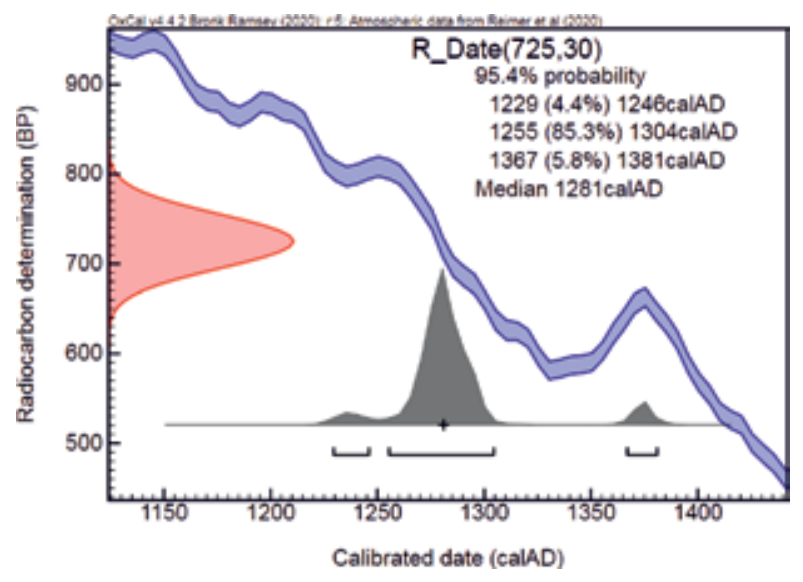

Obr. 14. Divinka - Divina, poloha Hradisko. Rádiouhlíkové datovanie vzorky z druhej kolovej jamy z druhej línie fortifikácie.

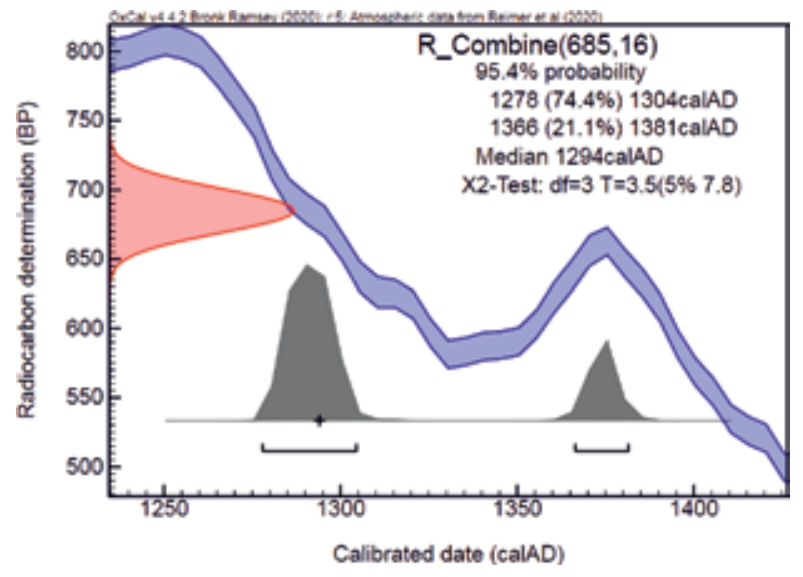

Obr. 15. Divinka - Divina, poloha Hradisko. Kombinačná kalibrácia rádiouhlíkovo datovaných vzoriek.

\section{HISTORICKÉ SPRÁVY}

Najstaršia historická zmienka o bezprostrednom okolí lokality Hradiska pochádza z roku 1244 (Kučáková/Velička 2015, 145, 146). Ide o donáciu krála Bela IV. trenčianskemu županovi Bohumírovi, kde je presne vymedzená zem „Kysuca“ na hraniciach s Pol'skom. Metačná hranica v našom záujmovo území postupuje od neznámeho „Brodi ci Lopata" cez hlavnú cestu do rieky Divina, ktorú prekračuje a následne postupuje po toku Malá Divina $\mathrm{k}$ jeho prameňom. Hoci nie je jednoznačne možné určit', ktorý z dnešných potokov je Malá Divina, ale ak je to akýkolvek prítok Diviny, skúmaná lokalita sa nachádza západne, mimo tohto vymedzenia. Výstavba hrádku, priamo kontrolujúceho túto hranicu, však nie je vylúčená ani mierne mimo metácie, a taktiež nie je možné úplne odmietnut' aj možný posun hraníc, ktorého zápis je ešte neznámy alebo sa nedochoval. Ked’že pri tejto časti hranice nie sú uvádzaní susední majitelia ako $\mathrm{v}$ iných častiach, je taktiež možné, že dnešná lokalita Hradisko bola priamo pod správou župy a nie v osobnom vlastníctve Bohumíra (Buchta 2012, 35). Bohumír dostal za úlohu túto momentálne opustenú či vyludnenú zem opevnit, k čomu sa však už zrejme nedostal, ked’že v roku 1254 bola králom ako odúmrt’ darovaná rodu Balašovcov, ktorí si ju pripojili $\mathrm{k}$ už vlastnenému Varínskemu panstvu (Buchta 2013, 57; Kučáková/Velička 2015, 147). V neskoršom období patrila zem Kysuca, zvaná Yesesin dvom bratom. Biterovi, ktorý vlastnil aj Žilinu a Petrovi, zvanému Forró, ktorý bol po prvotnom priatel'stve známym odporcom krála Ladislava IV., počas ktorého vlády násilne pripájal $\mathrm{k}$ svojím dŕžavám aj susedné majetky. Stalo sa tak napríklad v prípade Varína, ktorý pripojil k Sučanom a následne bol donútený ho vrátit' (Maliniak 2005, 90, 91). Obaja bratia boli osobne konfrontovaní s udaním, že si Yesesin prisvojili neprávom a vyzvaní predostriet listinné dôkazy (Buchta 2013, 58, 59). Obžalovaní boli Sebeslavom, synom Bohumíra, ktorý podla A. Buchtu nebol potomkom prvého známeho Bohumíra a ide o zhodu mien, kedže zem bola predtým po jeho smrti navrátená královi ako odúmrt’ (Buchta 2013, pozn. 51). Na základe osoby, ktorú za seba poslal ako hodnoverného svedka, lektora Bartolomeja z Nitry je ho však možné stotožnit’ s členom rodu Ludanických. Lektor Bartolomej bol totiž aj svedkom či zapisovatelom obchodných transakcií v rámci rodu Ludanických, medzi Sebeslavom a jeho bratrancom Vítkom (Nagy a i. 1866, 38, 39). Výsledok jednania nie je známy, kedže sa listinné spisy z tohto sporu nezachovali, no v d’alších správach už Sebeslav nefiguruje a Biter, a následne jeho synovia sú spomínaní ako majitelia hradov a zeme v okolí. Biter 
kúpil aj panstvo a hrad Hričov (Buchta 2013, 68), a čo je dôležité, on alebo jeho synovia mohli stát aj za výstavbou veže v Budatíne, ktorá im bola odňatá Matúšom Čákom a vrátená v roku 1321 (Janura 2019, 36). Niekedy v tomto období, avšak azda už po smrti Petra niekedy pred rokom 1290, bola vyplienená aj Biterova Žilina útočníkmi so známymi menami no neznámym pôvodom, komesom Štefanom, Gudom, Tomášom zo Svätého Kríža, Pavlom, Veličom, Matejom a Goldom (Buchta 2013, 67-69).

Na prelome storočí bolo toto územie vo víre mocenskej anarchie, tak ako zvyšok Uhorského královstva. Matúš Čák, pôsobiaci ako hegemón v celej Trenčianskej župe, zabral blízke bytčianske panstvo nitrianskemu biskupovi (Sedlák 2002, 91) a kastelán Lietavského hradu Ondrej, pod ktorý zrejme patrili aj obce Divina a Divinka (Janura 2018, 56), bol jedným z exkomunikovaných šlachticov lojálnych Čákovi (Sedlák 2002, 95). Zvyšok balašovskej domény v okolí Kysúc bol nejakým, nie presne známym spôsobom taktiež zabraný Matúšom Č́ákom, kedže po jeho prirodzenej smrti im král okrem iného vrátil hrady Hričov, Budatín, Lietavu a Varín, odňaté zrejme niekedy po roku 1305 (Buchta 2013, 76). Zostáva však otázkou, či Biterovym dedičom nebola v istej miere ponechaná aspoň čast’ majetkov, kedže ich nie je vidno vystupovat' $\mathrm{v}$ písomných prameňoch, ani $\mathrm{v}$ rámci stažností voči úplnému zabratiu ich vlastníctva (Buchta 2013, 78, 79). Oblast' Diviny a Divinky však mohli stratit, ak ju ešte kontrolovali, a Čákom zabratá zem bola daná do správy inému vernému familiárovi, ako je potvrdené v d’alších písomných správach. Č́ákom zabraté hrady sa po jeho smrti v roku 1321, po krátkom navrátení Balašovcom dostali naspät do královských rúk a boli spravované kastelánmi. Lietavský hrad a jeho panstvo pripadlo do správy krajinským sudcom, medzi ktorých patril prominentný šlachtic Alexander (Buchta 2013, 82, 83). Prvá konkrétna zmienka o Hradisku pochádza $\mathrm{z}$ roku 1325, v listine ktorou práve tento Alexander vyčlenil zem Divina, ktorú dal za úlohu osídlit istému Salmanovi (Sobola 2018, pozn. 5). Tu je opísaná hranica od Lúk okolo Krížového dubu po „Hradište“ a od „Hradišta” po „Rochne“. Opät sa spomína aj „Brodišová lopata“, potvrdzujúc tak aspoň približne lokalizáciu prvej zmienky z roku 1244, v ktorej sa však „Hradište“ nespomína, hoci samotná jej lokalizácia a exaktné stotožnenie s lokalitou z prvej písomnej zmienky je problematické (Velička 2017, $57,58)$. Je možné polemizovat', či v tomto prípade nebol myslený Vel'ký vrch. V danom roku vydania listiny však je možné, že opevnenie na Hradisku stále plnilo svoj účel, alebo prestalo len pred krátkou dobou, zatial' čo valy na Vel'kom vrchu, hoci určite viditelné a dominantné, svoju úlohu už neplnili po stáročia. Taktiež, pri uvádzaní metačnej hranice bol určite vhodnejší tento bod než dvanásthektárové hradisko. Z listiny nepriamo vyplýva, že v danom období sa zrejme z kompaktnejšej zeme, predtým zvanej Kysuca či Yesesin, začali vyčleňovat menšie celky. Opísaná zem svojou južnou hranicou približne rešpektovala aj dnešné hranice medzi katastrami Diviny a Divinky. Na záver listiny sa ešte spomína, že ide v podstate len o potvrdenie skoršej donácie, ktorú Salmanovi udelil vel'ký župan Matúš, akiste Matúš III. Čák.

\section{FUNKCIA A ZÁNIK OPEVNENIA}

Pri hladaní odpovede na otázku, aká bola funkcia hrádku na Hradisku je možné uvažovat’ o troch základných variantoch, vojenskej, kontrolnej a rezidenčnej, medzi ktorými je samozrejme istý prienik. V prvej písomnej mienke o zemi Kysuca, ktorá minimálne sčasti zahŕňala aj skúmané územie, je explicitne nariadené obdarovanému Bohumírovi ju opevnit (Buchta 2012, 36, pozn. 49). Nebyt výsledkov rádiouhlíkového datovania, na základe materiálnej kultúry a tejto listinnej zmienky by bolo najlogickejšie predpokladat', že hrádok na Hradisku bol postavený práve županom Bohumírom a mal primárne vojenskú funkciu na zabezpečenie hraníc. Zapadal by tak do komplexu fortifikácií vystavaných po vpáde Mongolov v rokoch 1241-1242 (Pow 2019). Podla súčasných poznatkov existoval krátku dobu, bez možnosti vyčlenenia viacerých archeologicky doložených fáz. Jeho výstavbu je nutné hladat' v záverečnej štvrtine 13. stor., v období ked' túto čast’ župy vlastnili predkovia rodu Balašovcov, bratia Biter a Peter, prípadne vel'mi krátko po zabratí územia Matúšom Cákom, kedy ho mohol založit aj spomínaný Salman. Vystavanie rezidenčného sídla, z ktorého by noví majitelia mohli túto donáciu ovládat je logickým krokom, ktorý však nie je podporený archeologickými nálezmi. V keramickom materiáli je len minimálne zastúpenie luxusnejšej tenkostennej keramiky a absentujú akékolvek iné hnutelné nálezy, ktoré by poukazovali, že tu sídlila spoločensky vyššie postavená osoba. Samozrejme, že nie je možné vylúčit, že takéto doklady bud' len neboli archeologickým výskumom zachytené, nedochovali sa, alebo tu sídlil len nižšie postavený familiár, ktorý si okrem samotnej výstavby opevnenia nemohol dovolit luxusnejšie zariadenie. $\mathrm{V}$ tomto prípade by sa však objavila dalšia otázka, ktorou je hospodárske zázemie. V prvej listine je zem označovaná za opustenú či pustú, a rovnako tak aj v donácii Salmanovi je akcentovaný pojem, že ide o prázdnu lokalitu, ktorú je potrebné osídlit' (Kučáková/Velička 2015, 150, 151). Nemáme tak priamo doložené žiadne dedinské osídlenie, ktoré 
by bolo schopné zásobovat prítomného nižšieho šlachtica. Je však možné pracovat' s hypotézou, že takáto dedina vznikla po roku 1244 a zanikla spolu s hrádkom niekedy počiatkom 14. stor., podobne ako sa to udialo s Krásnom nad Kysucou v približne rovnakom období (Kučáková/Velička 2015, 151, 152). Rezidencia osoby, ktorá osídlovala okolie by bola logickým krokom, avšak na základe archeologických dokladov o datovaní opevnenia na vrchu Hradisko nie je možné ju potvrditt.

Pri pohlade na možnú kontrolnú funkciu je nutné zohl'adnit prítomnost̉ dôležitých stredovekých komunikácií. Hradisko sa nachádza severne od rieky Váh, v jej relatívnej blízkosti, avšak nie takej, že by mohol kontrolovat priamo jeho tok, ako by to bolo možné napríklad z Vel'kého vrchu. Všetky kamenné hrady s výnimkou Varína, dnes nazývaného Starý hrad, a Považského hradu a veže v Budatíne boli na lavom brehu Váhu. V prvej listine o zemi Kysuca je však jasne čitatel'né, že hlavná cesta, Via Magna, prechádzala minimálne v blízkosti Divinky po pravej strane Váhu. Všeobecne sa za bod, kde sa hlavná cesta stáča na sever považuje Budatín, odkial pokračuje cez Kysuckú bránu na Kysucké Nové Mesto a d’alej na Jablunkovský priesmyk (Šimko 2019, 25-27, obr. 16). Nie je možné vylúčit ani variant, že cesta sa už v okolí Divinky stáčala na sever a obchádzala kopec Rochovica zo západu (Bednár/Vojteček/Daňová 2017, 29, obr. 10). Cesta by sa tak vyhla pomerne nepriestupnému miestu Kysuckej brány. Zmienky o ceste v blízkosti Hradiska je možné sledovat aj v metácii Budatínskeho panstva v roku 1438 (Bednárl Vojteček/Daňová 2017, 30).

Na českej strane hraníc, v rámci Moravy aj Sliezska je možné sledovat posun osídlenia smerom $\mathrm{k}$ dnešným slovenským hraniciam $\mathrm{v}$ druhej polovici 13. stor. (Kouřil/Žáček 1986, 100-103). Drobné opevnené lokality, rámcovo datovatelné do záveru 13. až prelomu 14. a 15. stor., je možné sledovat' $v$ dvoch líniách, na Jablunkovsku a na rieke Ostravici vo Frýdecko-Místecku (Kouřil/Žáček 1986, obr. 1). Najbližšie lokalite Hradisko je možné sledovat dvojicu obdobne datovaných polôh z dvoch strán Těsňovského priesmyku, Celadná (Kouřil/Žáček 1986, 122-124, obr. 16, 17) a Bílá (Kouřil/Prix 1995; Kouřill Žáček 1989). V polohe Čeladná sa našli obdobné keramické fragmenty ako na Hradisku (Kouřil/Žáček 1986, obr. 17: 5, 6) a nevyobrazený hrot šípu, v Bílej taktiež už vyššie spomínaný hrot s kvadratickým prierezom čepele. Oba body vel'mi pravdepodobne kontrolovali spojnicu medzi Uhorskom a Moravou v najsevernejšom mieste. Lokalita Bílá bola vybudovaná pred polovicou 14. stor., azda niekedy v jeho tridsiatych rokoch (Kouřil/Prix 1995, 49, 50). Celadnú je možné datovat' len široko na základe keramických fragmentov, rovnako ako d’alšie opevnené polohy z povodia Ostravice, do záveru 13. až 14. či 15. stor. (Kouřil/Žáček 1986, 122). Hoci o období prvej tretiny 14. stor., kedy zrejme vznikli tieto hrádky, existuje písomná zmienka o Hradisku, nie je jasné, či ešte stále pretrvávala jeho funkcia. Vo všeobecnosti však nie je možné vylúčit, že popri primárne používanému Jablunkovskému priesmyku pri ceste do Sliezska existovala aj druhá cesta cez Divinku a Divinu do priesmykov v okolí Makova. Mohla byt' kontrolovaná z hrádku na Hradisku a z druhej strany pohoria hrádkami v Bílej a Čeladnej. Rovnako ako na českej strane je možné pozorovat v regióne Kysúc relatívny nárast opevnených polôh v priebehu 14. a predovšetkým v 15. stor. Takéto hrádky nachádzame v Gbelanoch, Kotrčinej Lúčke (Bednár 2019) a v Turí (Moravčík 2002), na Hradisku však už vel'mi pravdepodobne opevnenie neplnilo svoju funkciu a rozrastala sa tam siet’ dedinského osídlenia.

Na vojensko-obrannú funkciu hrádku, ktorá by vyplývala z prvej písomnej zmienky o zemi Kysuca, poukazuje jeho poloha v blízkosti konfínia s Pol'skom a sčasti aj s Moravou, strohý charakter akcentujúci obrannú funkciu a sčasti aj pomerne početné nálezy militáríi. Na bod strategického záujmu poukazuje aj samotný zánik lokality, ktorá na základe výsledkov archeologického výskumu padla za obet’ silnému požiaru, ktorý prepálil oba valy do sýtej červenej farby. Nálezy hrotov šípov, koncentrujúcich sa na hornej terase vrcholovej plošiny, zrejme taktiež poukazujú na to, že oheň nevznikol náhodne a na hrádok niekto zaútočil. Z písomných prameňov je možné identifikovat troch možných útočníkov. $V$ prípade, že Hradisko patrilo pod správu Bitera a jeho synov je možné uvažovat,' že útok, pri ktorom bola vyplienená Žilina mohol istým spôsobom zasiahnut aj skúmaný hrádok. Podla prídomku jedného z útočníkov, zo Svätého Kríža, čo je dnešný Žiar nad Hronom, je možné predpokladat,' že na Žilinu zaútočili z juhovýchodu či juhu v smere od Rajeckej doliny (Buchta 2013, 67-69) a Divinka by tak nebola $\mathrm{v}$ ich ceste. Zánik $\mathrm{v}$ tomto období by znamenal len vel'mi krátke trvanie využívania tejto lokality a mohol by vysvetlit neprítomnost' v neskorších listinách. Na druhú stranu, Biter ako poškodený by pri žalobe komesa Štefana zaiste neopomenul vypálenie svojho hrádku. Nehovoriac o tom, že samotná Žilina predstavovala omnoho vhodnejší objekt útoku než malé a silno fortifikované miesto bez možnosti bohatej koristi.

Druhou časovou udalostou, ktorá môže súvisiet' s dobytím a vypálením hrádku na Hradisku môže byt๋ expanzia Matúša Čáka v prvých dekádach 14. stor. Matúš získal královské majetky v Trenčianskej a Nitrianskej stolici legálne v roku 1302, medzi ne však nepatrili osobné majetky šlachticov. 
V prípade okolia Diviny a Divinky zrejme Biterovych synov, ktorí boli stále ešte ako stúpenci Ladislava V. Č́kovými spojencami. To sa zmenilo hned' v najsledujúcich rokoch, ked' Matúš III. Čák prestal Ladislava V. podporovat’ a aspoň naoko sa pridal na stranu Karola Róberta. V tomto období vojensky zabral majetky Balašovcov na strednom Slovensku a zrejme taktiež na Považí a nechal si ich vo vlastnej správe (Buchta 2013, 75). V prípade, že majitel'mi Diviny a Divinky boli stále Balašovci, je možné, že tejto expanzii podlahol aj malý hrádok na Hradisku, o čom sa nemuseli zachovat explicitné písomné správy, ked’že viac priestoru pri opise škôd bolo venovaných práve hradom na strednom Slovensku. Pri výpočte hradov severného Slovenska navrátených Balašovcom králom v roku 1321 sa už na zničený a zaniknutý hrádok nemuselo poukázat', ked’že už neplnil svoju funkciu. Z hladiska výstavby nie je možné opomenút ani možnost', že hrádok bol postavený v úplne posledných rokoch pravdepodobnosti podla rádiouhlíkového datovania a súvisí práve $s$ týmto čákovským zabratím územia a snahou o jeho obranu, najskôr voči útoku zo severu, od sliezskych či moravských hraníc. Proti tomuto tvrdeniu však stojí fakt, že už vtedy stála veža pri brode $\mathrm{v}$ Budatíne, a tak výstavba hrádku v pomerne lahko priechodnom teréne tým pádom strácala strategický význam. $\mathrm{V}$ prípade stavby $\mathrm{v}$ tomto období by bolo možné hladat' skôr rezidenčnú funkciu správcu Diviny Salmana, ktorá však nie je jasne datovatelná, ked'že pôvodná listina chýba (Kučáková/Velička 2015, 150). V prípade, že $C^{14}$ dáta sú brané ako exaktné, donácia a velmi rýchla výstavba hrádku v úplne prvých rokoch čákovskej expanzie $\mathrm{v}$ priestore sa však javí ako nepravdepodobná. Isté boje sa viedli v blízkosti Kysúc na Orave medzi Čákom a magistrom Dončom, taktiež z rodu Balašovcov, asi medzi rokmi 1313-1317 (Buchta 2013, 82). Nie je teda možné vylúčit ani menšie potýčky, pri ktorých by mohlo byt' zničené aj Hradisko, vtedy pod správou Čákovych familiárov.

\section{ZÁVER}

Archeologickým výskumom v rokoch 2018 a 2019 na lokalite Hrádok na rozhraní katastrov obcí Divina a Divinka bol odkrytý stredoveký hrádok s tromi líniami opevnenia. Vonkajšia hradba s drevozemnou konštrukciou a vnútornou priekopou obopínala pätu vrcholovej plošiny. Jej jadro bolo hlinené, $\mathrm{z}$ vonkajšej strany podporené drevenou konštrukciou z dubových brvien a výpletom z tenkých konárov. Druhá línia opevnenia bola vystavaná na hrane dolnej terasy vrcholovej plošiny. Išlo o hradbu so škrupinovou konštrukciou. Jadro tvorili drevené rošty zasypané hlinou. $Z$ vnútornej strany ho držala palisádová stena $\mathrm{s}$ kolmi uloženými v žlabe, z vonkajšej strany bolo obložené väčšími kameňmi. Na vrchu násypu stála drevená predprseň, ktorá pozostávala z drevených kolov zapustených do jej telesa v dvojmetrových rozstupoch, do ktorých boli v drážke uložené vodorovne kladené dosky alebo brvná. Ochodza bola vyložená menšími kameňmi. Na dolnej terase bolo taktiež odkryté jedno ohnisko, nebolo však možné identifikovat', či bolo vonkajšie alebo či sa nachádzalo vo vnútri zrubovej stavby. Ďalej pokračovala vrcholová plošina až na hornú terasu, chránenú palisádou uloženou do úzkeho žliabku. Na najvyššom bode hrádkov spravidla stávala veža, po ktorej sa však na Hradisku nezachovali žiadne stopy. Nepriamym dôkazom prítomnosti takejto stavby, okrem analógií na početných lokalitách, bola prítomnost pomerne vel'kého množstva mazanice v okolí palisádového žlabu a najmä v ňom. Dá sa predpokladat', že veža bola drevená.

Hnutelný materiál pochádzajúci z hradiska predstavujú najmä kusy mazanice, črepy keramických nádob a hroty šípov, pričom pre datovanie vhodné sú len posledné dve kategórie. Keramika je porovnatel'ná $\mathrm{s}$ nálezmi $\mathrm{z}$ vrcholnostredovekých lokalít $\mathrm{v}$ regióne aj $\mathrm{v}$ širšom okolí. Na základe analógií je ju možné rámcovo datovat' do 13. stor., azda jeho druhej polovice. Nenachádzajú sa tu totiž archaické typy charakteristické pre 12. stor., ani typická keramika 14 . stor. $S$ týmto datovaním korešponduje aj datovanie hrotov šípov. Tie predstavujú charakteristický typ objavujúci sa na území Uhorska, ale aj okolitých štátnych útvarov najmä v druhej polovici 13. a začiatkom 14. stor. Vd’aka kombinácii všeobecnej chronológie hnutelných nálezov a rádiouhlíkového datovania je možné pomerne bezpečne konštatovat', že hrádok na Hradisku bol vybudovaný v poslednej štvrtine 13. stor.

Hrádok na Hradisku je v závere 13. stor. najsevernejšie situované opevnenie $\mathrm{v}$ žilinskom regióne. $\mathrm{Na}$ otázku jeho funkcie sa však bez písomných zdrojov nepodarilo odpovedat'. Archeologický materiál, ktorý je pomerne kompaktný z časového hladiska vypovedá o krátkodobom používaní. Absencia luxusnejších typov keramiky či iných predmetov zas vedie $\mathrm{k}$ úvahe, že majitel' hrádku mal $\mathrm{k}$ životu praktický prístup, dôraz kládol skôr na vybudovanie kvalitného opevnenia než na zabezpečenie luxusu. Z hladiska historických súvislostí je najpravdepodobnejšie vysvetlenie, že tu sídlil familiár alebo dokonca priamo jeden z predkov významnej uhorskej šlachtickej rodiny Balašovcov. Lokalita mala význam najmä vd’aka bezprostrednej blízkosti 
hlavnej cesty pozdĺž rieky Váh, jednej z hlavných severo-južných komunikačných tepien severnej časti Uhorska a azda aj jej menších odbočiek smerujúcich cez Javorníky do Sliezska a na Moravu. Zánik hrádku mala najpravdepodobnejšie na svedomí expanzia Matúša III. Č́áka Trenčianskeho voči
Balašovcom, pri ktorej vyhorel a viac nebol obnovený. Jeho prvá a jediná stredoveká písomná stopa je zachovaná už len ako metačný bod $\mathrm{v}$ donácii na Divinu, ktorá však svedčí o stále pretrvávajúcom význame okolia riečky Divinky aj v období neskorého stredoveku.

\section{LITERATÚRA}

Bednár 2019 - P. Bednár: Drevozemné opevnenia v Kysuckej vrchovine. Vlastivedný zborník Považia 29, 2019, 253-264.

Bednár/Daňová 2008 - P. Bednár/K. Daňová: Pokračovanie výskumu v areáli zaniknutej stredovekej dediny v Nededzi. AVANS 2006, 2008, 30, 31.

Bednár/Vojteček/Daňová 2017 - P. Bednár/M. Vojteček/K. Daňová: Nález stredovekej cesty v katastri obce Nededza, okres Žilina. In: P. Šimko (zost.): Dejiny cestnej dopravy na Slovensku II. Žilina 2017, 25-39.

Beňko 1985 - J. Beňko: Osídlenie severného Slovenska. Košice 1985.

Buchta 2012 - A. Buchta: Kto vlastne bol župan Bohumír, šlachtic z prvej písomnej zmienky (1244) o Kysuciach? In: D. Pindur/M. Turóci a kol.: Šlachta na Kysuciach a jej susedia. Čadca - Český Tešín - Žilina 2012, 29-37.

Buchta 2013 - A. Buchta: Balašovci a Kysuce do roku 1323. Zborník Kysuckého múzea 15, 2013, 47-89.

Farkaš 2015 - Z. Farkaš: Stredoveké opevnenie Starý Zámok II pri Pezinku. Zborník SNM 109. Archeológia 25, 2015, 257-295.

Fusek 2019- G. Fusek: Pevnostný systém hradiska v Divinke. Vlastivedný zborník Považia 29, 2019, 211-242.

Fusek/Holeščák 2018 - G. Fusek/M. Holeščák: Najstaršie opevnenie Vel'kého vrchu v Divinke. In: Sídla, artefakty a čas... Zborník štúdií o dobe bronzovej a dobe halštatskej $k$ 75. narodeninám Ladislava Veliačika. Nitra - Vrútky 2018, 83-94.

Fusek/Holeščák 2019 - G. Fusek/M. Holeščák: Der Burgwall Großer Berg bei Divinka. Vorbericht. Študijné zvesti AÚ SAV 66, 2019, 161-171.

DOI: https://doi.org/10.31577/szausav.2019.66.9

Habovštiak 1972 - A. Habovštiak: Stredoveké hrádky na Slovensku. Vlastivedný časopis 21/1, 1972, 2-8.

Hanuliak 2007 - M. Hanuliak: Vrcholnostredoveká osada v Beckove. Archaeologia historica 32, 2007, 335-349.

Hanuliak 2018 - M. Hanuliak: Stredoveké sídlisko z 13. storočia v Beckove. Slovenská archeológia 66, 2018, 107-177.

Holeščák 2019 - M. Holeščák: Medieval archery equipment from the territory of Slovakia. Nitra 2019.

Janura 2018 - T. Janura: Od prvej písomnej zmienky z roku 1325 do 1 . svetovej vojny. In: M. Sobola a kol.: Divinka a Lalinok. Divinka, 2018, 56-70.

Janura 2019 - T. Janura: Stredoveký hrad podla písomných prameňov. In: P. Bednár/Z. Staneková/P. Šimko (zost.): Budatínsky hrad. Žilina 2019, 36-39.

Jaššo 2007 - F. Jaššo: Stredoveké hrádky na západnom Slovensku. Musaica 25, 2007, 123-140.

Kouřil 1997 - P. Kouřil: Die Burg Freudenstein in Schlesien und ihr Hinterland. In: Život v archeologii středověku.
Sborník př́spěvků věnovaných Miroslavu Richterovi a Zdeňku Smetánkovi. Praha 1997, 382-393.

Kouříl/Prix 1995 - P. Kouřil/P. Prix: Drobné středověké opevnění v Bílé. Acta historica et museologica Universitatis Silesianae Opaviensis 2, 1995, 46-58.

Kouřil/Žáček 1986 - P. Kouřil/R. Žáček: Drobná středověká opevnění v Pobeskydí a otázka jejich klasifikace. Časopis Slezského muzea 35/2, 1986, 97-138.

Kouřil/Žáček 1989 - P. Kouřil/R. Žáček: Středověké opevění v Moravskoslezských Beskydech. Castellologica Bohemica 1, 1989, 271-275.

Kučáková/Velička 2015 - E. Kučáková/D. Velička: Pramene $\mathrm{k}$ dejinám Kysúc I./I. Stredoveké pramene z obdobia 1244-1399. Terra Kisucensis 6, 2015, 135-173.

Malec 2010 - J. Malec: Drobné stredoveké fortifikácie na strednom Považí. Zborník SNM 104. Archeológia 20, 2010, 119-136.

Maliniak 2005 - P. Maliniak: Útok na hrad Zvolen v roku 1290 (útočníci, obrancovia a príčiny konfliktu). In: J. Meliš (zost.): Rytierstvo, element v živote stredovekého človeka. Trnava 2005.

Moravčík 1991 - J. Moravčík: Archeologické nálezy v Považskom múzeu v rokoch 1981-1985. Vlastivedný zborník Považia 16, 1991, 5-42.

Moravčík 2002 - J. Moravčík: Opevnenia severozápadného Slovenska. Vlastivedný zborník Považia 21, 2002, 7-36.

Nagy a i. 1866 - E. Nagy/I. Páur/K. Ráth/D. Veghély: Codex diplomaticus patrius III. Győr 1866.

Petrovský-Šichman 1955 - A. Petrovský-Šichman: Predhistorické hrady nad obcou Divinka pri Žiline. Nálezová správa 64/55. Dokumentácia AÚ SAV Nitra. Nepublikované.

Petrovský-Šichman 1964 - A. Petrovský-Šichman: Slovanské osídlenie severného Slovenska. Vlastivedný sborník Považia 6, 1964, 50-106.

Pow 2019 - S. Pow: Hungary's castle defense strategy in the aftermath of the Mongol invasion (1241-1242). In: T. Tkalčec/T. Sekelj Ivančan/S. Krznar/J. Belaj (eds.): Fortifications, Defence Systems, Structures and Features in the Past. Zagreb 2019, 239-250.

Ruttkay 1992 - M. Ruttkay: Príspevok k poznaniu malých stredovekých opevnení na juhozápadnom Slovensku. Archaeologia historica 17, 1992, 253-262.

Sedlák 2002 - V. Sedlák (ed.): Pramene k dejinám Slovenska a Slovákov IV. Pod vládou anjouovských králov. Bratislava 2002.

Slaná 2018 - A. Slaná: Najstaršie dejiny. In: M. Sobola a kol.: Divinka a Lalinok. Divinka 2018, 43-55.

Sobola 2108 - M. Sobola: Divinka, Lalinok a okolie. In: M. Sobola a kol.: Divinka a Lalinok. Divinka 2018, 415-420. 
Staneková 2013 - Z. Staneková: Sídlisková aglomerácia v Divinke so zretel'om na sídlisko Ohrádza. Vlastivedný zborník Považia 26, 2013, 9-24.

Šedo 1980 - O. Šedo: Záchranný výskum v Lopušných Pažitiach. AVANS 1979, 1980, 201-204.

Šimko 2019 - P. Šimko: Budatínsky hrad na križovatke ciest In: P. Bednár/Z. Staneková/P. Šimko (zost.): Budatínsky hrad. Žilina 2019, 25-34.

Vangl'ová 2010 - T. Vanglová: Stredoveká keramika na severozápadnom Slovensku. Študijné zvesti Aú SAV 48, 2010, 91-140.

Rukopis prijatý 20. 11. 2020

Abstract translated by Michal Holeščák, summary by Viera Tejbusová

Mgr. Michal Holeščák, PhD.

Archeologický ústav SAV

Akademická 2

SK - 94921 Nitra

michal.holescak@savba.sk
Velička 2017 - D. Velička: Dejiny osídlenia Kysúc. Martin 2017.

Vích 2016 - D. Vích: Hrad v Hrádníkách u Zářecké Lhoty na Choceňsku. Archaeologia historica 41, 2016, 133-166.

Vlkolinská 2007 - I. Vlkolinská: Torzo stredovekej dediny v Beluši. Slovenská archeológia 60, 2007, 23-107.

Vojteček 2015 - M. Vojteček: Stredoveké dedinské sídlisko v Bitarovej. Študijné zvesti Aú SAV 58, 2015, $169-186$.

\title{
Medieval Stronghold in Divinka and Divina
}

\author{
Michal Holeščák - Andrea Slaná
}

\section{SUMMARY}

The archaeological excavations at the site of Hradisko on the border of cadastral areas of Divina and Divinka villages in 2018 and 2019 uncovered a medieval stronghold with three lines of fortification. The outer defensive wall with earthen-wooden construction and an inner ditch encircled the foot of the plateau. The wall's core was made of clay and supported by a wooden construction of oak beams and wickerwork of thin wood. The second line of fortification was built on the edge of the lower terrace of the plateau. It was a wall with a shell keep construction. The core was made up of wooden grids covered with earth. From the inside, it was held up by a palisade with stakes embedded in a furrow, from the outside, it was tiled with large stones. On top of the rampart, there was a wooden breastwork consisting of wooden stakes embedded in its body $2 \mathrm{~m}$ far from each other. In the spaces between them, boards or beams were installed horizontally. The walkway was paved with small stones. On the lower terrace, one fire pit was uncovered. However, it was impossible to identify whether it was situated outside or inside a structure. The plateau continued as far as the upper
Mgr. Andrea Slaná, PhD.

Považské múzeum v Žiline

Topolová 1

slana.andrea@gmail.com terrace protected by a palisade embedded in a narrow furrow. There used to be a tower at the highest points of strongholds. Nevertheless, no traces of a tower have been preserved at Hradisko. Besides analogies at numerous sites, presence of a considerable volume of daub around the palisade furrow and mainly inside it was indirect evidence of such construction. We can assume that the tower was made of wood.

The movable material from the hillfort contains mainly pieces of daub, sherds of pottery vessels and arrowheads; only the last two mentioned categories are suitable for dating. The pottery is comparable with finds from the sites dated to the High and Late Middle Ages located in the region as well as its wider surroundings. Based on analogies, it can be approximately dated to the $13^{\text {th }}$ century, possibly its second half. There are no archaic types typical for the $12^{\text {th }}$ century nor pottery typical for the $14^{\text {th }}$ century. They represent a characteristic type occurring in the territory of Hungarian Kingdom as well as its neighbouring states in the second half of the $13^{\text {th }}$ century and in the beginning of the $14^{\text {th }}$ century in particular. Thanks to the 
combination of general chronology of movable finds and radiocarbon dating, it is possible to state rather reliably that the stronghold at the Hradisko hillfort was built in the last quarter of the $13^{\text {th }}$ century.

In the end of the $13^{\text {th }}$ century, the stronghold at Hradisko is the northernmost fortification in the region of Žilina. Nevertheless, the question of its function has not been answered. The archaeological material, which is rather compact, suggests its short-time use. Absence of more luxurious types of pottery or other artifacts, on the other hand, leads us to an assumption that the stronghold's owner had a practical attitude to life and put more emphasis on building of a high quality fortification than on luxury. From the aspect of the historical context, it is more probable that it was inhabited by a servant or even

Fig. 1. Divinka - Divina. Lidar scan of the area of the stronghold. Researched site is encircled.

Fig. 2. Divinka - Divina, site Hradisko. Plan of the site with the area of excavations (grey colour). Geodetical measurements M. Bartík.

Fig. 3. Divinka - Divina, site Hradisko. Profile of a ditch through first line of the fortification. Grey colour marks burned layers.

Fig. 4. Divinka - Divina, site Hradisko. Profile of a ditch through second line of the fortification. Grey colour marks burned layers, dotted lines shows pole holes projected on the profile.

Fig. 5. Divinka - Divina, site Hradisko. Photogrammetric plan of the ditch through second line of fortification of the stronghold after its' first widening. Authors G. Fusek and A. Arpáš.

Fig. 6. Divinka - Divina, site Hradisko. Visual reconstruction of construction technology of the second line of fortification before the complete filling of the gallery. Author of the reconstruction A. Arpáš. an ancestor of the Balassa family, one of eminent Hungarian noble families. The site was also important due to a main road in the immediate vicinity along the Váh river, one of the main north-south communications in the northern part of Hungary and possibly also smaller side roads leading across the Javorníky mountains to Silesia and Moravia. The site's extinction was probably caused by expansion of Matthew III Csák of Trenčín against the Balassa family. During the expansion, the stronghold was burned and has never been renewed. Its first and the only medieval written trace has been preserved in form of a delimitation point in the donation document for Divina, which, however, documents the surviving importance of the Divinka river's surroundings as late as the Late Middle Ages.

Fig. 7. Divinka - Divina, site Hradisko. Visual reconstruction of the second line of the stronghold's fortification's profile. Author of the reconstruction A. Arpáš.

Fig. 8. Divinka - Divina, site Hradisko. Firepit excavated on the lower terrace of the plateau.

Fig. 9. Divinka - Divina, site Hradisko. Iron arrowheads from the site.

Fig. 10. Divinka - Divina, site Hradisko. Sample of a pottery shards from the site.

Fig. 11. Divinka - Divina, site Hradisko. Radiocarbon dating of the oak wood from the first line of fortification.

Fig. 12. Divinka - Divina, site Hradisko. Radiocarbon dating of the plum wood from the first line of fortification.

Fig. 13. Divinka - Divina, site Hradisko. Radiocarbon dating of the sample from first pole hole from the second line of fortification.

Fig. 14. Divinka - Divina, site Hradisko. Radiocarbon dating of the sample from second pole hole from the second line of fortification.

Fig. 15. Divinka - Divina, site Hradisko. Combination calibration of the radiocarbon dated samples 